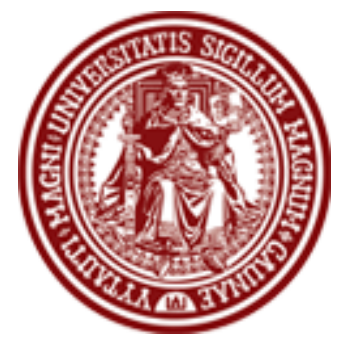

BALTIC JOURNAL OF LAW \& POLITICS

VOLUME 4, NUMBER 1 (2011)

ISSN 2029-0454

http://www.versita.com/bjlp

Cit.: Baltic Journal of Law \& Politics 4:1 (2011): 202-242

DOI: $10.2478 / v 10076-011-0009-0$

\title{
LITHUANIA'S PARTICIPATION IN THE RECONSTRUCTION PROCESS OF AFGHANISTAN: \\ A CASE OF A SMALL STATE'S ENGAGEMENT IN THE \\ INTERNATIONAL ARENA
}

\author{
Ringailè Kuokštytė \\ Doctoral Student \\ Panthéon-Sorbonne (Paris 1) University, Department of Political Science, \\ International Relations (France) \\ Contact information \\ Address: 17, rue de la Sorbonne, 75231 Paris, France \\ Phone: (+33) 147051318 \\ E-mail address: Ringaile.Kuokstyte@malix.univ-paris1.fr
}

Received: May 19, 2011; reviews: 2; accepted: July 28, 2011.

\begin{abstract}
Because the international arena is too focused on the interests of big states as structuring international interactions, small states continue to appear merely as objects (versus subjects) in the eyes of a large number of researchers, sometimes unconsciously following the (neo)realist tradition of International Relations (IR). Consequently, small states appear to be devoid of any analytical interest. In fact, such a trend in the field of IR neglects the significance of ever increasing interactions between states. Moreover, these interactions need not reflect incompatible interests of different states. The article argues that the case of the reconstruction process of Afghanistan, implemented by the international community, presents a positive-sum logic. In other words, the efforts of the coalition in the Afghan territory allow the engaged states, be they big or small, to pursue their own interests. The degree of their contributions corresponds to the benefits their engagement might provide. As the analysis of the Lithuanian case demonstrates, a small state need not be a passive object
\end{abstract}


trapped in the interactions of powerful states and can arrange itself in order to proceed with actively pursuing its own foreign policy.

\section{KEYWORDS}

The theory of collective action, public goods, international socialization, international norms, the war on terror, the Afghan war 


\section{INTRODUCTION}

The practice of international community engagement in regions suffering from all kinds of unrest is far from being a novel tendency in the inter-state arena. Yet we should rather talk about a multidimensional practice, since it is seldom of a homogeneous nature and is rarely characterized by the same degree of intensity. To put it differently, divergences might be detected not only in international engagement strategies, for instance, at the tactical or operational levels, but also in the predisposition of states or international institutions to pledge their commitment.

The general analytical framework of this article draws on the reconstruction activities carried out by the international community in Afghanistan. More precisely, the empirical center of attention will be limited to the Lithuanian government's engagement in this process.

The international conflict in question might seem to lack empirical, theoretical and moral challenges for researchers in the field of IR. This is mostly due to the seemingly crystal-clear solidarity of the allies with regard to international efforts to combat terrorism. It is however assumed in this article that academic discussions or research on the process of reconstruction of Afghanistan are far from being exhausted, especially if one wishes to understand the complexity of interactions between the allies. Furthermore, as far as Lithuania specifically is concerned, constructive debates on Afghanistan are absent at the national level, which might confirm that the Lithuanian government's obligation to contribute to the global security remains unquestionable and cannot generate any additional argument, apart from those put forward by the Western countries (such as defending Western civilization $\left.{ }^{1}\right)$.

The Lithuanian engagement in Afghanistan as a study case can contribute to answering the question whether it is possible for a small state to pursue its own national interests on an international scale. The article does not intend to evaluate the ongoing conflict on moral grounds.

My research issue should not be associated with the academic debates or methodology, entitled to classify states on a strictly quantitative basis. The current analysis is supposed to eventually negate the relevance of such debates. ${ }^{2}$ It will also relativize the (neo)realist thesis of IR, which focuses on the rationality as well as pre-determined interests of states, and according to which small states are limited in their actions because of the impact of structural forces at the

\footnotetext{
${ }^{1}$ NATO, "Address to the Nation by Valdas Adamkus, President of the Republic of Lithuania, in Response to Terrorist Attack in the US," (September 14, 2001) // http://www.nato.int/pfp/lt/speeches/2001-0914.html (accessed June 5, 2010).

2 Robert O. Keohane, "The Big Influence of Small Allies", Foreign Policy No. 2 (Spring 1971): 162.
} 
international level. ${ }^{3}$ The analysis will shed some light on the fact that the observed political reality might correspond to different theoretical frameworks (in this case, the classical and constructivist traditions of IR). The methodology and methods applied will be largely qualitative research and the analysis of political statements as well as interviews, respectively.

I argue that the Lithuanian government's active and coherent efforts in the process of reconstruction of Afghanistan correspond to Lithuania's national interests as they are officially recognised. The engagement of the international community on the Afghan territory represents a practical framework which facilitates the implementation of these interests.

The analysis provided in this article is based on the assumption of the complexity of international social interactions, and the Afghan conflict is perceived as reflecting different motives of the allies, i.e. other than fear of terrorism. Interests of small and big allies need not be mutually exclusive. Furthermore, as I will argue, it is more expedient to replace the concept of state power by the one of influence. ${ }^{4}$

Lithuania is primarily recognised as a small state based on the material dimension. Moreover, Lithuania has relatively recently turned into a subject in the international arena. Although it joined NATO and the European Union in 2004, this westward integration is not without tension: a lack of solid democratic and freemarket experience in the case of Lithuania equates to "a leap from the league $B$ to the premier league". ${ }^{5}$ Hence the question: how can Lithuania's willingness to identify itself with Europe and be part of it be asserted empirically? The answer does not appear to be an easy one, especially if one considers that "segments of western society", as noted by Michel Dobry, "repeatedly express their reticence, resistance, or out-right rejection of overtly intimate connections with Central and Eastern Europe". ${ }^{6}$

The recognition of a historically peripheral dimension of Eastern Europe with regard to the Western countries ${ }^{7}$ allows for considering Lithuania's engagement in Afghanistan as the state's efforts to better integrate within the West. This

\footnotetext{
${ }^{3}$ Iver B. Neumann and Sieglinde Gstöhl, "Introduction. Lilliputians in Gulliver's World?": 10; in: Christine Ingebritsen, ed., Small States in International Relations (Seattle: University of Washington Press, 2006). ${ }^{4}$ Ibid.: 5.

5 Česlovas Laurinavičius, Raimundas Lopata, and Vladas Sirutavičius, "Kritinis požiūis i Lietuvos užsienio politiką: kas pasikeitè nuo Augusto Voldemaro laiku? [A Critical Approach towards the Lithuanian Foreign Policy: What Has Changed since the Times of Augustas Voldemaras?]", Politologija Vol. 54, No. 2 (2009): 102.

${ }^{6}$ Michel Dobry, "Introduction: When Transitology Meets Simultaneous Transitions": 1; in: Michel Dobry, ed., Democratic and Capitalist Transitions in Eastern Europe. Lessons for the Social Sciences (Dordrecht: Kluwer Academic Publishers, 2000).

7 Maria Mälksoo, The Politics of Becoming European: A Study of Polish and Baltic Post-Cold War Security Imaginaries (London: Routledge, 2010), p. 29.
} 
assumption might be validated by the Lithuanian foreign policy declared objective of Lithuania's becoming a full-fledged member of NATO and the EU. ${ }^{8}$

Firstly, I proceed by analysing the Atlanticism-related security dimension ${ }^{9}$ relative to the Eastern European region. I will try to reveal the ways in which, via its engagement in Afghanistan, the Lithuanian government is successful at consolidating the country's national security. Secondly, a discussion of Lithuania's command of the Provincial Reconstruction Team (PRT) of the province of Ghor will follow. I will argue that this type of engagement provides the Lithuanian government with more credibility as to its ambition to pursue a normative foreign policy.

\section{THE CONSTRUCTION OF A LITHUANIA-SPECIFIC SECURITY FIELD}

The international community engagement in Afghanistan, having resulted from the terror attacks of September 11 against the US, conforms to the collectivesecurity logic. In this case, the objective to be collectively eliminated is the existing terror threat. It is however argued here that the international coalition member states are apt to pursue their own specific security interests which need not be equivalent to the declared combat against terrorism. ${ }^{10}$ Such an articulation of state interactions allows for assuming an interrelationship between the degree of intensity of a given country's engagement and the national (or private versus collective) benefits procured in the process.

\subsection{THE COLLECTIVE ACTION LOGIC}

Terrorist networks might be analysed as a transnational challenge, i.e. apt to incapacitate sovereign states to guarantee their national security by their own efforts $^{11}$, hence the necessity of international cooperation, which usually faces difficulties relative to collective action. ${ }^{12}$

The concept of collective action, which can be defined as "a more or less coordinated process of collective mobilization, having as its target to defend a specific group's symbolic or material interests"13, provides a possible axis of

\footnotetext{
8 Foreign Policy Programme of the Government of the Republic of Lithuania (November 17, 2008) // http://www3.Irs.It/docs2/KCQRLFQZ.PDF (accessed March 23, 2010).

${ }^{9}$ I will note that here Atlanticism is conceived in terms of perception of the US as an existential security guarantor by the Central and Eastern European countries.

${ }_{10}$ Erich Reiter, "Introductory Comments on the Objective of the Small States and Alliances Workshop": 13; in: Heinz Gärtner and Erich Reiter, eds., Small States and Alliances (Heidelberg: Physica-Verlag, 2001).

11 Josepha Laroche, Politique internationale [International Politics], $2^{\text {nd }}$ ed. (Paris: L.G.D.J., 2000), p. 89.

12 Todd Sandler, Global Collective Action (New York: Cambridge University Press, 2004), p. 165.

13 Olivier Nay, ed., Lexique de science politique [Glossary of Political Science] (Paris: Editions Dalloz, 2008), p. 2.
} 
analysis for the process of reconstruction of Afghanistan. Following this logic as well as referring to Mancur Olson Jr. and Richard Zeckhauser's theory of collective action ${ }^{14}$, it is further argued that the war against terror in Afghanistan and the aspiration of the allies for international peace and security reflect their common interest. ${ }^{15}$

If we add to the analysis of collective action the Kantian tradition, which appeals to the universal benefits of a peaceful and secure international arena, it might be argued that in the Afghan case peace and security are public goods in their own right. ${ }^{16}$ Yet public goods are characterized by two essential specificities: non-exclusion and indivisibility. ${ }^{17}$ They result in the famous collective-action dilemma. As for international security, this dilemma might be summarized as follows: small states would tend to free ride or to bring minimal contributions to the collective efforts, since their material resources, by far more limited than those of powerful states, will only have a slight impact on the final outcome in terms of security. On the contrary, the dominating state will have to bear much larger costs induced by the collective action than a proportional calculation of material resources possessed by the allies would imply. ${ }^{18}$

This conceptual framework can be illustrated by concrete examples: as noted for example by Todd Sandler, the US is obviously a dominating power in the fight against the Taliban; since the American interests remain the main target of terrorists, Washington is to benefit most, once international security and peace are re-established. ${ }^{19}$ The lack of determination from the rest of NATO member countries to bring sufficient contributions in terms of human and financial resources to Afghanistan seems to be one of the reasons of failing activities of the allies. ${ }^{20}$

Yet such a homogenization of defective engagement from different NATO member countries in Afghanistan can distort the analysis of international relations in general and of international cooperation in particular. Furthermore, it might distort the very formation of foreign policy strategies. Too much focus drawn to big

14 Mancur Olson Jr. and Richard Zeckhauser, "An Economic Theory of Alliances," The Review of Economics and Statistics Vol. 48, No. 3 (1966).

${ }_{15}$ This assumption might be validated by fragments of declarations made by the UN Security Council after the September 11 events (United Nations Security Council, Resolution 1368 (September 12, 2001) // http://daccess-dds-ny.un.org/doc/UNDOC/GEN/N01/533/82/PDF/N0153382.pdf?OpenElement (accessed February 18, 2010).

16 Marie De Jerphanion, "Vers un rapprochement de la morale et de la Realpolitik ? [Towards a Rapprochement between the Morality and Realpolitik?]" Revue internationale et stratégique Vol. 67, No. 3 (2007): 130.

17 Andrew Bennet, Joseph Lepgold, and Danny Unger, Friends in Need: Burden Sharing in the Gulf War (Bloomsburg: Macmillan Press Ltd, 1997), p. 5.

${ }^{18}$ Ibid., p. 4-5.

19 Todd Sandler, supra note 12 , p. 181.

20 Timo Noetzel and Sibylle Scheipers, "Coalition Warfare in Afghanistan: Burden-Sharing or Disunity?" Chatham House (2007) //

http://www.chathamhouse.org.uk/files/9878_bp1007afghanistan.pdf (accessed February 18, 2010); Daniel Korski, "Afghanistan: Europe's Forgotten War," European Council on Foreign Relations (2008) // http://ecfr.3cdn.net/fcdc73b8da7af85936_q8m6b5o4j.pdf (accessed March 5, 2010). 
and powerful states with regard to their positioning in the Afghan conflict dismisses their smaller counterparts. Contrary to the theory of collective action, some of them, such as Lithuania, appear to be actively committed therein.

\subsection{LITHUANIA AS A SMALL STATE}

The position of big states with regard to the Afghan issue constitutes merely one aspect allowing for a better understanding of the international arena. It can as well be analysed from the perspective of small states. These are by far less resistible to shifts in the international system, which makes their analysis rich in valuable insights on international relations. ${ }^{21}$

Although I tend to dismiss the relevance of a quantitative categorization of states as a research demarche unable to generate substantial discussions (the What? question versus the Why? or How? questions), the quantitative methodology allows for inscribing Lithuania among small states. This starting point keeps my analysis within the framework of the (neo)realist tradition, which is important since this very tradition provided my research question.

The Afghan issue presents several elements conforming to the classical theory of IR, the security theme and the military nature of the conflict being the most obvious ones. With regard to security, some authors tend to perceive it as a direct outcome provided by the possession of military means. ${ }^{22}$ Consequently, a potential engagement of the member states of a given alliance might be measured according to their military capacity. ${ }^{23}$ As considered by the classical tradition, the physical dimension of a state (or its relative power capacities) influences its security and foreign policy. ${ }^{24}$ Suffering from lacking material resources, small states seek additional means which might contribute to the enhancement of their national security.

Considering conceptual efforts to define a small state, it seems that no universally relevant definition has been found. ${ }^{25}$ However, efforts have been made in the domain: for instance, Tom Crowards tends to categorize states, including the small ones, on the basis of three rigidly objective criteria: population size, area

\footnotetext{
${ }^{21}$ Laurent Goetschel, "The Foreign and Security Policy Interests of Small States in Today's Europe": 14; in: Laurent Goetschel, ed., Small States Inside and Outside the European Union: Interests and Policies (Dordrecht: Kluwer Academic Publishers, 1998).

22 Barry Buzan, Ole Waever, and Jaap De Wilde, Security: A New Framework for Analysis (London: Lynne Rienner Publishers, 1998), p. 49.

${ }_{23}$ Erik Männik, "Small States: Invited to NATO - Able to Contribute?" Defense \& Security Analysis Vol. 20, No. 1 (2004): p. 23.

${ }^{24}$ Laurent Goetschel, "Introduction": 9; in: Laurent Goetschel, ed., Small States (...), supra note 21.

25 Jeanne A. K. Hey, "Introducing Small State Foreign Policy": 2; in: Jeanne A. K. Hey, ed., Small States in World Politics: Explaining Foreign Policy Behavior (Boulder: Lynner Rienner Publisher, 2003).
} 
$\left(\mathrm{km}^{2}\right)$ and GDP. ${ }^{26}$ Robert L. Rothstein appealed in his turn to the very perception states have as to the international arena. He considered a state as being small if it was aware of not being capable to ensure its national security by its own means. ${ }^{27}$ Such a psychological dimension of states, also recognised by Robert O. Keohane ${ }^{28}$, would however require more explanations than it could provide answers, so I will limit myself to the physical parameters.

It is as well to be noted that, with the view of avoiding a too much ample diversification of engagement of the allies in Afghanistan, I will focus on the NATO member states. ${ }^{29}$ This methodological choice is due to the assumption that contributions of the member states of the Alliance to the Afghan reconstruction efforts should reflect proportionally similar quantitative and similar qualitative specificities because of more rigid commitments associated with an alliance than it would be the case, for instance, in a coalition. ${ }^{30}$

If we briefly and simply compare the physical data of the 28 NATO member countries, we will notice that there are only 6 countries with a smaller population than Lithuania ${ }^{31}$; Lithuania's area in terms of $\mathrm{km}^{2}$ is larger than that of its 10 counterparts $^{32}$; and as for the GDP per capita (estimated in US dollars), Lithuania scores better than only 4 other NATO member countries. ${ }^{33}$ Hence it is doubtful if a relative quantitative smallness of Lithuania would allow Olson Jr. and Zeckhauser to deduce an active participation of Vilnius in Afghanistan. Yet such simplistic considerations should be controlled by a more detailed empirical perspective.

\subsection{LITHUANIA'S ACTIVE PARTICIPATION}

Lithuania engaged in the American-led military operation "Enduring Freedom" in November 2002 and participated in it with a 45-soldier troop until the end of 2006. ${ }^{34}$ In February 2005 the then American Secretary of Defense Donald

26 Tom Crowards, "Defining the Category of Small States," Journal of International Development 14 (2002).

27 Robert L. Rothstein, Alliances and Small Powers (New York: Columbia University Press, 1968).

28 Robert O. Keohane, "Lilliputians' Dilemmas: Small States in International Politics," International Organization Vol. 23, No. 2 (1969).

${ }^{29}$ Today 48 states participate in the ISAF activities (Afghanistan International Security Assistance Force, "ISAF: Key Facts and Figures," (March 4, 2011) //

http://www.isaf.nato.int/images/stories/File/Placemats/PLACEMAT.MARCH\%2004..pdf (accessed March 6, 2011)).

30 Volker Krause and David Singer, "Minor Powers, Alliances, and Armed Conflict: Some Preliminary Patterns": 16; in: Heinz Gärtner and Erich Reiter, eds., Small States and Alliances (Heidelberg: PhysicaVerlag, 2001).

${ }^{31}$ World Bank, "Population, Total" //

http://data.worldbank.org/indicator/SP.POP.TOTL (accessed May 17, 2010)).

32 World Bank, "World Development Indicators 2010": 32-34 //

http://data.worldbank.org/sites/default/files/wdi-final.pdf (accessed April 22, 2011).

${ }^{33}$ World Bank, "GDP Ranking" //

http://siteresources.worldbank.org/DATASTATISTICS/Resources/GDP.pdf (accessed May 17, 2010)).

34 Ministry of Foreign Affairs of the Republic of Lithuania (MFA), "Afghanistan" (2010), Information document communicated via e-mail by Valdemaras Sarapinas, the then Senior Counsellor, Afghan 
Rumsfeld, while addressing his speech during a NATO conference in Munich, gave tribute to Lithuania as a state contributing to the NATO ISAF efforts in Afghanistan in a significant manner. Earlier that year the former NATO Secretary General Jaap de Hoop Scheffer had as well appealed to the Vilnius example: "If Lithuania can do it, others can do it too." ${ }^{35}$

These tributes were the result of the Lithuanian government's decision to take up the command of the PRT of Ghor. The responsibility entrusted to Vilnius was part of the process of expanding the ISAF to the West of the Afghan territory, with the view of ensuring a smooth undergoing of parliamentary elections. ${ }^{36}$ The PRT led by Lithuanians is an international team consisting of representatives from the US, Denmark, Japan, Georgia, Poland, Finland and Ukraine. ${ }^{37}$

Although the Afghan PRTs are not uniquely of military nature (the civil dimension will be analysed subsequently), it is in fact primarily up to the military element to provide necessary grounds for reconstructing and stabilizing the territory by civil and humanitarian means. ${ }^{38}$ Based on this consideration, it is argued that contributions of states to the international community efforts in Afghanistan are to be primarily associated with the material aspect. ${ }^{39}$

As of March 2011, within the ISAF Lithuania was represented by 188 soldiers ${ }^{40}$, whose largest majority was deployed in Ghor. ${ }^{41}$ Lithuania also deploys military personnel from the squadron of special forces "Aitvaras". ${ }^{42}$ Since the official

Project Coordinator (March 31, 2010). This article is based on research carried out within the framework of a Master thesis which was finalized in June 2010. The majority of the interviews with Lithuanian ministerial and parliamentary authorities, referred to in this article, were realized by e-mail correspondence. A few information documents mentioned in the article were also provided by specific authorities via e-mail.

35 Vladimir Socor, "Lithuania to Lead NATO Unit in Afghanistan," Eurasia Daily Monitor Vol. 33, No. 2 (2005) // http://www.jamestown.org/single/?no_cache=1\&tx_ttnews\%5Btt_news \%5D =27547 (accessed May 22, 2010).

${ }^{35}$ Ibid.

${ }^{36}$ Ibid.

37 Mindaugas Jackevičius, "R.Juknevičienè: i Afganistana nesiunčiame nè pusès kariu, kiek leidžia Seimas [R.Juknevičienè: We Do Not Send to Afghanistan Even Half of the Soldiers Allowed by the Seimas]," Delfi.lt (April 6, 2011) // http://www.delfi.lt/news/daily/lithuania/rjukneviciene-i-afganistananesiunciame-ne-puses-kariu-kiek-leidzia-seimas.d?id=44067047 (accessed April 12, 2011).

38 Major Matthew Swannell, Bill Moeller, and HQ ISAF PRT Office, ISAF PRT Handbook, 3rd ed. (February

3, 2007): 4, Information document communicated via e-mail by Bartas Trakymas, the then Assistant-

Director of the International Operations Unit, Ministry of Defense (MoD) (April 14, 2010).

${ }^{39}$ Robert Cooper, La fracture des nations. Ordre et chaos au XXI siècle [The Breaking of Nations. Order and Chaos in the Twenty-First Century] (Paris: Denoël (Médiations), 2004), p. 183-204.

${ }^{40}$ Afghanistan ISAF, "ISAF: Key Facts and Figures," supra note 29.

${ }^{41}$ MFA, "Lietuvos veikos Afganistane status quo [Status Quo of the Lithuanian Activities in Afghanistan]," (February 7, 2010), Information document communicated via e-mail March 31, 2010, by Sarapinas.

42 The number of soldiers serving in military operations is not rendered public. NATO, "Specialiuju operaciju pajègu eskadronas Aitvaras vèl visu pajègumu dalyvaus tarptautinèje operacijoje Afganistane [The Squadron of Special Operation Forces Aitvaras Will Participate Again with All its Capacities in the International Operation in Afghanistan]," (April 13, 2010) //

http://www.nato.It/specialiuju-operaciju-pajegu-eskadronas-\%e2\%80\%9eaitvaras\%e2\%80\%9c-velvisu-pajegumu-dalyvaus-tarptautineje-operacijoje-afganistane/ (accessed May 30, 2010). 
number of national soldiers within the ISAF is constantly changing, we will look at the average numbers. ${ }^{43}$

The average in the Lithuanian case amounts to 195 soldiers. If we calculated, based on these average numbers of national troops, the ratio measuring the Lithuanian population's representation within the ISAF (i.e. how many Lithuanians can be attributed to one national soldier deployed), Lithuania would appear more active than 20 other NATO member countries.

\begin{tabular}{|c|c|c|c|}
\hline Country & $\begin{array}{l}\text { Average number of } \\
\text { national soldiers } \\
\text { deployed within ISAF } \\
\text { (January 2007- March } \\
\text { 2011) }\end{array}$ & Population & $\begin{array}{l}\text { Population attributed } \\
\text { to } 1 \text { national soldier } \\
\text { deployed within } \\
\text { ISAF }\end{array}$ \\
\hline UK & 8225 & 61406928 & 7466 \\
\hline US & 39072 & 304375000 & 7790 \\
\hline Denmark & 661 & 5493621 & 8311 \\
\hline Estonia & 132 & 1340675 & 10157 \\
\hline Norway & 467 & 4768212 & 10210 \\
\hline Netherlands & 1538 & 16445593 & 10693 \\
\hline Canada & 2687 & 33311400 & 12397 \\
\hline Lithuania & 195 & 3358115 & 17221 \\
\hline Croatia & 249 & 4434000 & 17807 \\
\hline Bulgaria & 424 & 7623395 & 17980 \\
\hline Albania & 163 & 3143291 & 19284 \\
\hline Latvia & 109 & 2266094 & 20790 \\
\hline Italy & 2722 & 59832179 & 21981 \\
\hline Romania & 959 & 21513622 & 22433 \\
\hline Germany & 3637 & 82110097 & 22576 \\
\hline France & 2581 & 62277432 & 24129 \\
\hline Poland & 1577 & 38125759 & 24176 \\
\hline Belgium & 435 & 10708433 & 24617 \\
\hline Czech Republic & 359 & 10424336 & 29037 \\
\hline Slovenia & 68 & 2021316 & 29725 \\
\hline Hungary & 303 & 10038188 & 33129 \\
\hline Slovakia & 159 & 5406626 & 34004 \\
\hline Spain & 951 & 45555716 & 47903 \\
\hline Iceland & 6 & 317414 & 52902 \\
\hline Luxemburg & 9 & 488650 & 54294 \\
\hline
\end{tabular}

43 The ISAF archives represent official statistical data of national soldiers from the year 2007; the last data included in my calculations dates to March 4, 2011 (Afghanistan ISAF, "ISAF Placement Archives," (March 2011) // http://www.isaf.nato.int/isaf-placemat-archives.html (accessed March 10, 2011)). 


\begin{tabular}{|l|c|c|c|}
\hline Turkey & 1137 & 73914260 & 65008 \\
\hline Greece & 127 & 11237094 & 88481 \\
\hline Portugal & 118 & 10622413 & 90020 \\
\hline
\end{tabular}

As for the expenditure for military activities, it is to be noted beforehand that the defense budget of Lithuania is one of the most miserable ones among the NATO member states: in terms of the poorest national expenditure for defense within the NATO framework, Lithuania ranks (together with Belgium) 25-26. ${ }^{44}$ Yet with regard to Lithuania's engagement in Afghanistan, these considerations seem to be relative, since the expenditure of the Lithuanian Ministry of Defense (MoD) for international missions have been constantly increasing, be it in terms of percentage or real numbers. ${ }^{45}$ Since participating in the Alliance activities in Afghanistan is recognised by the Lithuanian MoD as the prime priority among international missions worldwide, the largest part of the budget allocated in this domain goes to the reconstruction mission of Ghor. ${ }^{46}$

These several insights attest to Lithuania's effort to adhere to the camp of member states actively engaged in the NATO ISAF, especially if one takes into consideration human and financial resources allocated to Afghanistan in the context of national priorities. This Lithuanian foreign policy strategy seems to stand in contradiction to the theory of collective action as well as to the thesis according to which "[s]mall states rarely have vital national interests at stake in conflicts distant from their territories". ${ }^{47}$

\subsection{THE LITHUANIAN POLITICAL DISCOURSE}

Lithuania's as an active ally's credibility is even more reinforced by the national political discourse. In fact, it contributes to legitimizing, be it at the national or international level, important Lithuanian contributions in terms of financial and human resources deployed in the Afghan territory.

\footnotetext{
44 NATO, "Financial and Economic Data Relating to NATO Defense. Defense Expenditure of NATO Countries," (February 19, 2009) // http://www.nato.int/docu/pr/2009/p09-009.pdf (accessed May 23, 2010).

${ }^{45}$ Army of the Republic of Lithuania, "Tarptautiniu operaciju finansavimas [The Financing of International Operations]," (2010) //

http://kariuomene.kam.It/It/tarptautines_operacijos_786/tarptautiniu_misiju_finansavimas.html (accessed May 23, 2010).

${ }^{46}$ MoD, "2008 m. krašto apsaugos sistemos biudžetas [The budget of the Ministry of Defense in 2008]," Krašto apsauga Vol. 14, No. 143 (2008): 1 //

http://www.kam.It/lt/naujienos_874/karine_ziniasklaida_655/krasto_apsauga_718/2008_m._krasto_aps augos_numeriai/krasto_apsauga_2008_m._rugpjutis.html (accessed May 23, 2010).

47 Renatas Norkus, "Lithuania's Contribution to International Operations: Challenges for a Small Ally," Baltic Security \& Defense Review 8 (2006): $168 / /$

http://www.bdcol.ee/fileadmin/docs/bsdr/8-Small\%20Allies\%20in\%20International\%200perations-

Renatas\%20Norkus.pdf (accessed March 18, 2010).
} 
The Lithuanian engagement in Afghanistan is officially declared as the country's most important international mission in terms of soldiers sent and financial resources contributed. ${ }^{48}$ In the Strategy of the Participation of the Republic of Lithuania in the International Community Activities in the Islam Republic of Afghanistan $2009-2013^{49}$ an emphasis is put on the fact that the Lithuanian national institutions responsible for the state's engagement within the ISAF "essentially" agree as to the "strategic [...] elements" of this engagement.

Such an agreement is echoed by the solidarity of politicians and governmental authorities as well as by the lack of constructive political debates on the issue. As noted by a MFA representative, the political elite members do provide "real support" for the Afghan issue. ${ }^{50}$ Members of the Lithuanian parliament seem to have no difficulty in prolonging the mandate of Lithuanian military units to serve in international operations. ${ }^{51}$ The interviewed Lithuanian representatives largely confirmed the existing consensus on the issue..$^{52}$

In the above mentioned Lithuanian Strategy ${ }^{53}$, the country's participation in the international community activities in Afghanistan is qualified as contributing to the defense of national interests and fulfilling international duty, so that Vilnius could be recognised as a "responsible member of the Transatlantic community". This engagement thus appears as perfectly conforming to the national governmental programme of Lithuania for 2008-2012: it states that the Lithuanian government "will ensure that Lithuania would be a responsible and active NATO member, implementing its engagements to the Alliance, contributing, correspondingly to its national capacities, to the security reinforcement of the Transatlantic community and to fighting against international terrorist structures" ${ }^{54}$

\footnotetext{
48 MFA, Information document for the Minister of Foreign Affairs A. Ažubalis (March 31, 2010), Document communicated via e-mail by Sarapinas (March 31, 2010).

49 Lietuvos Respublikos dalyvavimo tarptautinès bendruomenès veikloje Afganistano Islamo Respublikoje 2009-2013 mety strategija [Strategy of the Participation of the Republic of Lithuania in the International Community Activities in the Islam Republic of Afghanistan 2009-2013], Adopted by the decision No 989 of the Government of the Republic of Lithuania, (August 19, 2009) //

http://www3.Irs.It/pls/inter3/dokpaieska.showdoc_I?p_id=351998\&p_query=\&p_tr2= (accessed January $15,2010)$.

${ }_{50}$ E-mail interview with Danas Vaitkevičius, the then Counsellor at the MFA Latin America, Asia and Pacific Department (May 2, 2010). It is to be noted that the interviews were carried out with several high-level ministerial representatives, namely from the Ministry of Defense and the Ministry of Foreign Affairs, and those of the largest party of the Seimas, Homeland Union-Lithuanian Christian Democrats (representatives from other parties having not responded).

51 MFA, "Lietuvos veikos Afganistane status quo [Status Quo of the Lithuanian Activities in Afghanistan]" (March 22, 2010), Information document communicated via e-mail by Sarapinas (March 31, 2010).

${ }^{52}$ E-mail interview with Egidijus Vareikis, member of the Seimas (April 14, 2010); e-mail interview with Arvydas Anušauskas, President of the National Security and Defence Committee of the Seimas, (April 20, 2010); e-mail interview with Saulius Pečeliūnas, member of the Seimas (May 12, 2010).

${ }^{53}$ Strategy of the Participation (...), supra note 49.

54 On the Adoption of the Implementation Means of the Programme of the Government of the Republic of Lithuania for 2008-2012, Decision No. 189 adopted by the Government of the Republic of Lithuania (February 25, 2009) //

http://www3.Irs.It/pls/inter3/dokpaieska.showdoc_I?p_id=354702\&p_query=\&p_tr2= (accessed May 24, 2010).
} 
From a conceptual point of view, the Lithuanian case might be considered as an "empirical anomal[y]" of collective action. ${ }^{55}$ Yet, as I will try to show, it allows for answering affirmatively to Olson Jr. and Zeckhauser's question as to whether national interests influence the intensity of a given state's engagement within the framework of collective action. ${ }^{56}$ In other words, semi-private or private benefits provided simultaneously with the collective ones contribute to a more equal burden-sharing. Small states in alliances indeed appear to be capable of pursuing strategic actions, with the view of ensuring their own security, while at the same time contributing to the stability and efficiency of international structures. ${ }^{57}$ This assumption is largely compatible with the idea of diverging threats which influence security interests of different states.

\subsection{FEAR OF RUSSIA'S NEIGHBOURHOOD}

Lithuania's solid identification with NATO within the framework of the Afghan conflict is associated in the article with Atlanticism: as argued by Česlovas Laurinavičius, Raimundas Lopata and Vladas Sirutavičius, the integration to the West made Lithuanian politicians seek support on the side of "the strongest". ${ }^{58}$ I argue that the Afghan conflict provides Vilnius with the possibility to gain security dividends from the American government vis-à-vis Russia.

The fear of Russia, still relevant in Eastern Europe, corresponds to the conception of traditional fear, which appeals to geographical proximity of the USSR successor and the recent memory of the Soviet occupation. ${ }^{59}$

Although one might discern some signs of political rechauffement, especially after new Lithuanian President Dalia Grybauskaitè came into power ${ }^{60}$, such optimistic considerations have not yet endured the challenge of longevity, which would make their analysis somewhat speculative. Moreover, popular reaction as it is voiced in national media with regard to the above-mentioned rechauffement appears to be negative. ${ }^{61}$ However, it does not seem relevant to seek sophisticated causes having brought about such social realities in the region: the Russo-

\footnotetext{
55 Andrew Bennet, Joseph Lepgold, and Danny Unger, supra note 17, p. 5.

56 Ibid.

57 Heinz Gärtner, "Small States and Alliances": 5; in: Heinz Gärtner and Erich Reiter, eds., Small States and Alliances, supra note 30 .

58 Česlovas Laurinavičius, Raimundas Lopata, and Vladas Sirutavičius, supra note 5: 102.

59 Rick Fawn, "Alliance Behaviour, the Absentee Liberator and the Influence of Soft Power: PostCommunist State Position over the Iraq War in 2003," Cambridge Review of International Affairs Vol. 19, No. 3 (2006): 472.

60 Audrius Bačiulis, "Rusija netikètai atsigręžè i Lietuvą [Russia Has Unexpectedly Turned to Lithuania]," Veidas (February 15, 2010): 18-19.

61 For example, Marius Laurinavičius, "Akibrokštai partneriams taps Lietuvos užsienio politikos kasdienybe? [Will Lapsus Become Part of the Lithuanian Foreign Policy Daily Life?]", Lrytas.It (April 9, 2010) //

http://www.Irytas.It/-12707989501269486198-m-laurinavi\%C4\%8Diaus-blogas-akibrok\%C5\%A1taipartneriams-taps-lietuvos-u\%C5\%BEsienio-politikos-kasdienybe.htm (accessed May 26, 2010 ).
} 
Lithuanian relations can be explained by the argument that "long-lasting years of wars, servitude, national oppression, and Russification shaped the approach towards Russia as an eternal and extremely dangerous enemy" ${ }^{62}$

At this point we might briefly refer to the messages which appeared in the Lithuanian as well as international media as to the Baltic trio's reaction to the French-Russian commercial deal concerning Mistral military ships ${ }^{63}$. Military analysts in the Baltic states voiced their fear that "the vessels would change the balance of power in the region". ${ }^{64}$ Yet in order to reveal a more profound significance of this transfer, it is necessary to refer to a third category of actors, i.e. France and Germany, the biggest European states, which tend to provide Russia with preferential treatment, at the expense of the Baltic interests. ${ }^{65}$

Intellectual efforts to conceptualize EU-Russian relations are certainly well known to the Lithuanian academic tradition. For instance, Lopata, when analysing the EU's rapprochement to Russia, argues for the former's conviction that Russia is indispensible in creating "the European security architecture". ${ }^{66}$ Vytautas Radžvilas, in his turn, notes that the ultimate objective of relations between the most influential EU member states and Russia is "a long-standing strategic partnership" ${ }^{67}$ In this light, the transfer of Mistral military ships might be perceived not as "an ordinary technical affair", but as a germ of a military and political alliance; this mutual rapprochement is even more facilitated by the post-Cold-War absence of ideological or political obstacles. ${ }^{68}$ Moreover, Brussels and Moscow might also find common grounds in their anti-American stance and aspiration to come back to "the foreground of the world history and politics." ${ }^{69}$

62 Evaldas Nekrašas, "Kritiniai pamastymai apie Lietuvos užsienio politiką [Critical Reflections on the Lithuanian Foreign Policy]," Politologija Vol. 54, No. 2 (2009): 131 // http://www.leidykla.vu.It/fileadmin/Politologija/54/123-142.pdf (accessed March 15, 2010).

63 Isabelle Lasserre, "Le Mistral, objet flottant de convoitises [The Mistral: A Floating Objet of Covetousness]," Lefigaro.fr (April 8, 2010) // http://www.lefigaro.fr/international/2010/04/09/0100320100409ARTFIG00003-lemistral-objet-flottant-de-convoitises-.php (accessed May 27, 2010).

${ }^{64}$ AP, "Nato Air Forces to Train over Baltic Countries," (March 2, 2010) //

http://seattletimes.nwsource.com/html/nationworld/2011229377_apeunatobalticairpatrols.html?syndicat ion=rss (accessed March 2, 2010).

${ }^{65}$ Rick Fawn, supra note 59.

66 Raimundas Lopata, "Europos Sajunga ir Rusija: ka reiškis "ir"? [European Union and Russia: What does "and" mean?]," Lrytas.It (May 14, 2010) // http://www.Irytas.It/-12738269801271897730europos-s\%C4\%85junga-ir-rusija-k\%C4\%85-rei\%C5\%A1kia-ir.htm (accessed May 24, 2010).

67 Vytautas Radžvilas, "Tiesos valanda: neivykusi valstybè II (Pamąstymai Europos dienos proga) [The Moment of Truth: A Non-Occurred State II (Reflections on the Occasion of the Europe Day)]," Lrytas.It (April 29, 2010) // http://www.Irytas.It/-12725411511270481841-tiesos-valanda-ne\%C4\%AFvykusivalstyb\%C4\%97-ii-pam\%C4\%85stymai-europos-dienos-proga.htm (accessed May 24, 2010).

${ }^{68}$ Ibid.

69 Vytautas Radžvilas, "Tiesos valanda: neivykusi valstybè I (Pamąstymai Europos dienos proga, skiriama šviesiam L. Kaczynskio atminimui) [The Moment of Truth: A Non-Occurred State I (Reflections on the Occasion of the Europe Day, Dedicated to the Memory of L. Kaczynski)]," Lrytas.lt (April 22, 2010) //

http://www.Irytas.It/-12719341291269894654-tiesos-valanda-ne\%C4\%AFvykusi-valstyb\%C4\%97-ipam\%C4\%85stymai-europos-dienos-proga-skiriama-\%C5\%A1viesiam-I-kaczynskio-atminimui.htm (accessed May 24, 2010). 
Some criticism might be addressed to this perception of EU security and foreign policy of Realpolitik nature, especially by mobilizing Robert Cooper's argument according to which Europe, as opposed to the US, avoids comprehending the international arena as obeying power relations. ${ }^{70}$ As argued by Cooper, Europe has renounced power politics, and its aim is to once and for all sterilize Western Europe from strategies based on force and threat variables. ${ }^{71}$

It is in fact Cooper's conception of European security that seems to worry the Eastern European states and provokes their Euro-scepticism in that domain. In other words, they tend to criticise Europe for taking too soft an approach vis-à-vis Russia. At the same time, they gravitate towards the US pole as far as security politics is concerned. ${ }^{72}$ The importance attributed by the Central and Eastern European countries to military force is simply and clearly explained once again by Cooper: the collapse of the Soviet Union is associated in the region with a steadfast American position rather than the European spirit of contact and dialogue. ${ }^{73}$ This historically significant event resulted in specific deep-rooted associations manifest in the region, such as the re-establishment of national independence thanks to military power.

As argued by Barry Buzan, security is one of the state action stimuli, as is the case with power; however, consequent state action trajectories as to these respective motives are not the same. ${ }^{74}$ According to Buzan, the classical tradition of IR perceives states as obeying the logic of fight for power, while security is reduced to a mere outcome of the latter. ${ }^{75}$ Criticising such a materialist conception of security as too limited, Buzan argues for the complexity of security as a research object in its own right in social sciences. ${ }^{76}$

The inoperability of the concept of power is also obvious in the discussions about small states, since analysing state action trajectories based on the (material) power dimension reduces a small state's subjecthood in the international arena. ${ }^{77}$ On the contrary, the priority given to the pursuit of state security (versus power) interests objectivize the general condition of states: in this case, all of them might be perceived as being able to pursue their own interests and, more importantly, to achieve favourable outcomes.

\footnotetext{
${ }^{70}$ Robert Cooper, supra note 39, p. 189.

${ }^{71}$ Ibid., p. 190.

72 Linas Linkevičius, "Life After Enlargement," Baltic Defence Review Vol. 1, No. 9 (2003): 106.

73 Robert Cooper, supra note 39, p. 189.

${ }^{74}$ Barry Buzan, People, States and Fear: An Agenda for International Security Studies in the Post-Cold War Era (Hertfordshire: Harvester Wheatsheaf, 1991), p. 3.

${ }^{75}$ Ibid., p. 8.

76 Ibid., p. 23.

77 Iver B. Neumann and Sieglinde Gstöhl, supra note 3: 26.
} 


\subsection{THE SOCIAL DIMENSION OF THE INTERNATIONAL ARENA}

For methodological reasons having rendered the material dimension less significant in the analysis of international relations, I simultaneously assume the possibility of existing different logics that underlie the action trajectories of states. As for national security, it is argued that it may be reinforced not only by a direct proliferation of material resources, but also thanks to the consolidation of a state's integration within international structures, hence the importance of the social aspect of the inter-state arena.

This social element is also at the basis of the process of securitization allowing states to proceed with creating new frameworks of global politics. ${ }^{78}$ According to Buzan, the threat of terrorism constitutes a successful "macrosecuritization" undertaken by Washington and it benefits from an ample intersubjective recognition as an existential threat, significantly influencing political processes on an international scale. ${ }^{79}$ The September 11 attacks indeed resulted in shifting priorities on the security agenda of the majority of states. ${ }^{80}$

As for Lithuania and terrorism, it is to be noted that the NATO Summit of November 2002 (Prague), during which discussions regarding the new NATO conception of war against terror took place, had a symbolic meaning for Lithuania, since it was invited to start negotiations for its membership in the Alliance. ${ }^{81}$ Lithuania's preparations for the process had already been started prior to that date: for example, in January of the same year, the Lithuanian government had adopted a programme against terrorism, stipulating participation in the international community activities to counter terror as one of the national priorities in the domain. ${ }^{82}$

Official statements taken over from the Western discourse and put forward by Lithuanian authorities as well as the setting up of new military units ${ }^{83}$ provide Lithuania with the possibility of being understood (contrary to its position with regard to Russia) and recognised by the international community as a member of the Western community.

\footnotetext{
78 Barry Buzan, "Will the Global War on Terrorism Be the New Cold War?" International Affairs Vol. 82, No. 6 (2006): 1102.

${ }^{79}$ Ibid.; Barry Buzan, Ole Waever, and Jaap De Wilde, supra note 22, p. 25.

80 For instance, MoD, Lietuvos nacionalinio saugumo strategija pateiks saugios ateities vizija [The Lithuanian National Security Strategy Is to Provide a Vision of a Secure Future], (February 18, 2002) // http://www.kam.It/It/naujienos_874/archyvas_930/ziniu_archyvas_2002_metai/ziniu_archyvas_200202/lietuvos_nacionalinio_saugumo_strategija_pateiks_saugios_ateities_vizija.html?backlink $=\% 252 \mathrm{Flt} \% 2$ 52Fpaieska\%252Fresults\%252Fp10.html (accessed May 29, 2010).

${ }^{81}$ NATO, "Prague Summit Declaration," (November 21, 2002) // http://www.nato.int/docu/pr/2002/p02127f.htm (accessed May 29, 2010).

82 MFA, "Kova su terorizmu [War Against Terrorism]" //

http://www.urm.It/index.php?-1810366038 (accessed May 29, 2010).

${ }^{83}$ Army of the Republic of Lithuania, "Ypatingosios paskirties tarnyba (YPT) [Special Purpose Service]" // http://kariuomene.kam.It/It/kariuomenes_struktura/specialiuju_operaciju_pajegos/ypatingosios_paskirti es_tarnyba_ypt.html (accessed April 25, 2010).
} 
The westward integration process of Eastern Europe is qualified for example by Maria Mälksoo as a struggle for recognition. This Estonian researcher has provided a theory of the politics of becoming relative to the Baltic trio and Poland within the security framework. ${ }^{84}$ According to Mälksoo, as far as the domain of foreign and security policy is concerned, the position of the Eastern European countries differs from the one of other EU member states in the sense that the security imaginary ${ }^{85}$ of the former camp is characterized by the fear of Russia and is based on a strong Atlanticist logic.

Referring to this perspective, we can argue that the threat of terror constitutes one of the practical axes along which the recognition of the Eastern European countries by their Western neighbours might take place. Achievements (and failures) within the evolution of this process of recognition might be sought in the political discourse; this choice of method is validated by the assumption that the above-mentioned securitization process is highly politicized, and one can analyse it directly ${ }^{86}$, that is to say, via public statements.

The solidity of the Lithuanian-American cooperation does not seem to have ever lacked strong political declarations: in March of the last year the American Ambassador to Lithuania Anne E. Derse expressed her satisfaction with the "superb security partnership" between Vilnius and Washington. ${ }^{87}$ Having paid tribute to Lithuania for its solid position with regard to the collective defense in Afghanistan, she distinguished the Lithuanian government as one of the largest contributors to the NATO efforts in Afghanistan in terms of the size of population and GDP.

Similar elements of such political discourse can also be detected in statements made by NATO officers in general ${ }^{88}$ and by the general secretary of the Alliance in particular. ${ }^{89}$ As for representatives of the Lithuanian elite, they tend to appeal to Lithuania's better recognition among the Alliance member states by putting forward a more weighty position of Vilnius in the process of decision-making within NATO. ${ }^{90}$

\footnotetext{
${ }^{84}$ Maria Mälksoo, supra note 7.

85 Ibid., p. 29-32.

${ }^{86}$ Barry Buzan, Ole Waever, and Jaap De Wilde, supra note 22, p. 25.

87 BNS, "Saugumo srityje Lietuvą ir JAV sieja puiki dvišale ir NATO partneryste [Lithuania and the US Has a Superb Bilateral Partnership in the Security Domain]," (March 25, 2010) // http://www.nato.It/jav-ambasadore-saugumo-srityje-lietuva-ir-jav-sieja-puiki-dvisale-ir-natopartneryste/ (accessed May 30, 2010).

88 ELTA, "Aukštas NATO pareigūnas: Lietuva - patikima NATO partnerè [A High-level NATO Official: Lithuania Is NATO's Trustworthy Ally]," (April 30, 2009) //

http://www.balsas.It/naujiena/250374/aukstas-nato-pareigunas-lietuva-patikima-nato-partnere (accessed May 30, 2010).

${ }^{89}$ Eglè Dirgytè, "A.F.Rasmussenas: nebūtu teisinio pagrindo pašalinti Lietuvą iš NATO [A.F.Rasmussen: There Would Be No Legal Foundation to Exclude Lithuania from NATO]," Delfi.lt (April 22, 2010) // http://www.delfi.It/news/daily/lithuania/afrasmussenas-nebutu-teisinio-pagrindo-pasalinti-lietuva-isnato.d?id=31381883 (accessed April 27, 2010).

90 BNS, "Audronius Ažubalis: dèl indèlio Afganistane Lietuva gali tarti griežtesni žodi NATO [Audronius Ažubalis: Thanks to Its Contributions to Afghanistan, Lithuania Is Able to Speak More Loudly within NATO]," (April 2, 2010) // http://www.balsas.It/naujiena/246236/audronius-azubalis-del-indelioafganistane-lietuva-gali-tarti-grieztesni-zodi-nato (accessed April 27, 2010).
} 
As for the security dimension, none of the interviewed representatives of the Seimas or the Ministry of Foreign Affairs (MFA) and the MoD put in question the Lithuanian engagement in Afghanistan as conforming to security interests; none of them provided any criticism as to Juknevičienè's statement that "contributing to NATO's budget is less painful than losing the [mission of] air police" ${ }^{\prime 1}$, which is recognised as the most efficient means of air defense in the region. ${ }^{92}$

In the case of Lithuania, it is indeed difficult to argue in favour of the relevance of either one or another threat (Russia versus terrorism). The task is even more complicated by the Lithuanian political elite's scepticism, closely related to the instrumentalization process. However, none of the provided threat perspectives contradicts the argument that Lithuania, within the framework of its engagement to the coalition's collective efforts in Afghanistan, is apt to gain private benefits. ${ }^{93}$ An active engagement of Vilnius guarantees its more solid recognition among the NATO allies.

Yet the analysis provided above is based on a state's rationality. It does not exhaust the complexity of the social aspect of international relations. In other words, it might be as well argued that public declaration of the duty and responsibility falling upon Lithuania to contribute to the ISAF should not be uniquely associated with pre-established strategic security interests that result from purely instrumental calculations. ${ }^{94}$ The previously mentioned official declarations might result from the Lithuanian political elite's newly gained consciousness of being part of Western civilization and reflect international norms. ${ }^{95}$

\section{THE CHALLENGE OF NORMATIVE LEARNING}

Having mobilized Buzan's thesis according to which states, institutions or the national territory of a country might be threatened not only by military force but also by the manipulation of ideas ${ }^{96}$, the security of states (or the lack thereof) might equally be considered as resulting not only from material power possessed

\footnotetext{
91 BNS, "R.Juknevičienè: pildyti NATO biudžetą mažiau skausminga nei prarasti oro policija [R. Juknevičienè: It Is Less Painful to Contribute to the NATO Budget than Lose the Air Police]," (February 10, 2010) //

http://www.alfa.It/straipsnis/10314711/?Jukneviciene..pildyti.NATO.biudzeta.maziau.skausminga..nei.pr arasti.oro. policija=2010-02-10_17-50 (accessed May 30, 2010).

92 BNS, "Kariumenès vadas V. Tutkus: NATO oro policija - vienintelè išeitis Lietuvai [The Chief of Army V. Tutkus: The NATO Air Police Is the Only Resort for Lithuania]," (July 20, 2006) // http://www.Irytas.It/-11541658091153759738-kariuomen\%C4\%97s-vadas-v-tutkus-nato-oro-policijavienintel\%C4\%97-i\%C5\%A1eitis-lietuvai.htm (accessed May 30, 2010).

93 Such as the NATO defense plans for the Baltic region (BNS, "D. Zalimas: apie konkrečius gynybos planus nekalbama samoningai [D. Žalimas: Nobody Speaks about Specific Defense Plans Consciously]," (April 15, 2010) //

http://www.delfi.It/news/daily/lithuania/dzalimas-apie-konkrecius-gynybos-planus-nekalbamasamoningai.d?id=31077633 (accessed April 15, 2010)).

${ }_{94}$ Maria Mälksoo, supra note 7, p. 138.

${ }^{95}$ Iver B. Neumann and Sieglinde Gstöhl, supra note 3: 19.

96 Barry Buzan, supra note 74, p. 97.
} 
but also from the promotion of and adherence to ideas recognised by the international community. For some authors like Ariel Colonomos, the dynamics of an ever increasing interstate cooperation on an international scale provides grounds for the argument of "world of partners"97; according to him, the international system has undergone a structural shift, which is reflected in an enhanced normative role of morality.

\subsection{REDEFINITION OF POWER IN FAVOUR OF SMALL STATES}

The Afghan conflict should not be exclusively associated with the strategy to counter insurgents, which is dominated by military force. From an ideological point of view, the war against terror is strongly linked to the defense of the Western liberal democratic civilization. The aim to establish a stable and pacific environment in Afghanistan is based on the logic of democratization, hence a normative content of the activities implemented by the allies in the region.

As argued by some authors, the tactics of soft (versus hard) power is by far more adequate to fight modern threats. ${ }^{98}$ Pursuing a deeper integration within the Western block, Lithuania adopts as its guiding principle internationally recognised norms. ${ }^{99}$

The idea that the international arena keeps changing bears no revolutionary character, especially within the academic world. I argue that at the centre of this process there are shifts of criteria which influence the standing of states. ${ }^{100}$ This assumption appeals to the constructivist theory of IR, emphasizing the importance of norms, ideas, state identities, etc. In the case of states, international norms might indeed amount to a significant resource, since their weight and influence on an international scale depend on a recognised normative element. The argument of social power and influence of states downplays if not rejects the discriminative perspective of military and economic force with regard to small states. For instance, the Scandinavian countries, thanks to their activism in the promotion of environment protection, international security and global welfare, have become

\footnotetext{
97 Ariel Colonomos, La morale dans les relations internationales [Morality in International Relations] (Paris: Odile Jacob, 2005), p. 267.

98 William Drozdiak, "The Brussels Wall," Foreign Affairs Vol. 89, No. 3 (May-June 2010): 7-12.

99 BNS, "P. Vaitiekūnas: Lietuvos veikla Afganistane - vienas didžiausiu tarptautiniu isipareigojimu [P. Vaitiekūnas: The Lithuanian Activities in Afghanistan Constitute One of the Most Significant International Engagements [of Lithuania]," (November 26, 2007) // http://www.vtv.It/naujienos/uzsienio-politika/p.vaitiekunas-lietuvos-veikla-afganistane-vienas-didziausiu-tarptautiniu-isipareig-3.html (accessed June 5, 2010).

100 Richard Ned Lebow, "Fear, Interest and Honour: Outlines of a Theory of International Relations," International Affairs Vol. 82, No. 3 (2006): 432.
} 
experts in these domains, and their strategy of advocating norms and ideas influences the very formation of their own foreign policy. ${ }^{101}$

Colonomos argues that the fall of the Berlin wall "radically" transformed the traditional vision of international politics. He tends to analyse the international reality as a social construct ${ }^{102}$ and recognises that values or "moral norms" exert an impact on state interests. ${ }^{103}$ It is then might be argued that today's international norms largely reflect specific elements of the Western morality. For instance, the project of cosmopolitan law ${ }^{104}$ may be associated with the Kantian imperative of morally-based practical reason. ${ }^{105}$ More concretely, according to French philosopher Pierre Manent, the cosmopolitan law that defends each person as such is embedded in humanitarian law. ${ }^{106}$ Institutionalization of these legal elements attests to the process of the moralization of the international arena. ${ }^{107}$

According to Colonomos, the moralization of the international arena is also reflected in the imperative of moral justification. ${ }^{108}$ For example, the Western states associated the September 11 events with attacks against freedom and democracy. Similarly, Lithuanian representatives described them as "a challenge to the whole civilized and democratic world, to freedom, the world community, principles of coexistence and humanism"109, to "the Western civilization and its values". ${ }^{110}$

The stance of the Lithuanian political elite, though intuitively rational, confirms Ned Lebow's thesis, according to whom "political units" are predisposed to adapt to the environment perceived as their own, and to gravitate towards influence leverages which they consider as the most efficient. ${ }^{111}$ Lithuania's command of a PRT then allows us to analyse the Afghan conflict as providing Lithuania with the possibility to gain a more solid recognition by its Western counterparts via promoting liberal democratic values.

\footnotetext{
101 Christine Ingebritsen, "Norm Entrepreneurs: Scandinavia's Role in World Politics": 275; in Christine Ingebritsen, ed., Small States in International Relations, supra note 3.

102 Ariel Colonomos, supra note 97, p. 11.

103 Ibid., p. 19.

104 Ibid., p. 265-310.

105 Pierre Manent, Cours familier de philosophie politique [Informal Course of Political Philosophy] (Paris: Gallimard, 2001), p. 301.

106 Ibid., p. 301-302. In the same conceptual framework, Colonomos argues that human rights constitute the cornerstone of the turning point towards the cosmopolitan perception (Ariel Colonomos, supra note 97 , p. 267).

107 Ariel Colonomos, supra note 97, p. 27, 232.

108 Ibid., p. 28.

109 NATO, "Statement by the Seimas of the Republic of Lithuania on the Acts of Terrorism against the USA," (September 12, 2001) // http://www.nato.int/pfp/lt/speeches/2001-09-12.html (accessed June 5, 2010).

110 NATO, "Address to the Nation," supra note 1.

111 Richard Ned Lebow, supra note 100: 436.
} 


\subsection{DEMOCRACY PROMOTION AS THE DECLARED PRINCIPLE OF LITHUANIAN FOREIGN POLICY}

As previously mentioned, the states engaged in Afghanistan implement various activities, starting from the ones of a military nature to the reconstruction of the country by peaceful means. Such favourable circumstances allow the Lithuanian government to inscribe its engagement in Afghanistan as corresponding to its normative foreign policy, considered here mainly as based on the promotion of democracy. ${ }^{112}$

The Lithuanian expertise (if not a comparative advantage) concerning the command of the PRT of Ghor might be sought in the national "experience of transition from autocracy to democracy and from planned to market economy, Eurointegration process, successful state-building". ${ }^{113}$ Vilnius should therefore be apt to help its neighbours carry out transformational processes. ${ }^{114}$ As for Ghor, Vilnius is implementing its efforts in the region in order to consolidate the rule of law, develop the country's economy and infrastructure, as well as to promote good practices, rights and liberties. ${ }^{115}$ Consequently, Lithuania seems to be acting within the framework of its declared political competence.

Democracy promotion corresponds to a normative dynamics typical of the Western community. Speaking of Afghanistan, the command of the PRT of Ghor, characterized by a strong civil dimension, confers on Lithuania greater visibility and might constitute a normative leverage. This assumption seems to be validated by the fact that the strategy of visibility and development cooperation is officially recognised as conforming to the principles of the Lithuanian foreign policy. ${ }^{116}$

\subsection{EXCEPTIONALITY OF LITHUANIA'S ENGAGEMENT}

Today there are 28 ISAF PRTs in the Afghan territory, and they are actually commanded by the following countries: Sweden, Germany, Norway, Hungary, Italy, Lithuania, the US, Spain, the United Kingdom, New Zealand, Turkey, the Czech Republic, and South Korea. ${ }^{117}$ Lithuania has been responsible for the command of Ghor since 2005.

\footnotetext{
112 Česlovas Laurinavičius, Raimundas Lopata, and Vladas Sirutavičius, supra note 5: 108.

113 Priorities for Lithuania's Development Cooperation Policy, Speech pronounced by Bernotas, former Chief of the Department of Multilateral Relations, MFA (June 8, 2006).

114 Debra Percival, "La politique lituanienne de développement se tourne vers I'Est [Lithuania's Development Policy Is Turning Eastwards]," Le Courrier 9 (2009) // http://www.acp-eucourier.info/Apolitica-de-desenvolvim.903.0.html?\&L=2 (accessed March 9, 2010)

115 MFA, "Lietuvos veikos Afganistane status quo," supra note 51.

116 Debra Percival, supra note 114.

117 Afghanistan ISAF, "ISAF: Key Facts and Figures," supra note 29.
} 
In this context Lithuania stands out as the state having adhered to NATO most recently and it is the sole country having joined the Alliance during the last two enlargement waves. In this sense, Lithuania's activism equals that of the Alliance old-timers. Lithuania's efforts appear even more credible if one considers a non-fortuitous character of the government's decision to engage in Afghanistan: its determination to command a PRT was already manifest when the NATO leadership submitted the proposition; at first the Baltic trio was offered the opportunity to command a PRT by collective effort. ${ }^{118}$ Latvia and Estonia having declined the offer, Lithuania agreed to take up the command on its own.

It is interesting to note that, in the eyes of the interviewed Lithuanian representatives, the concept of exceptionality does not seem to be avoided as to the country's efforts deployed in Afghanistan: Lithuania can be distinguished as the sole Baltic state entrusted with a PRT command ${ }^{119}$; also, the Lithuanian contribution might be described as "disproportionally significant", especially considering the fact that "no other country of such a size and of such limited resources has taken up a PRT command", which makes the Lithuanian mission "really grand". ${ }^{120}$

At this point, we might refer to another exceptionality-related manifestation in Lithuanian foreign policy, which is the idea of a regional centre. According to Evaldas Nekrašas, it should allow the Lithuanian political elite to gain more visibility. ${ }^{121}$ Generally speaking, visibility can be an important element of foreign policy: it provides a given foreign policy strategy with a symbolic dimension and might function as a leverage granting more significance to actions of the national government in question. The possibility to see "a big Lithuanian flag" in fact had a strong impact on the Lithuanian authorities as to the decision of taking up the command of a PRT. ${ }^{122}$

However, it is to be noted that the content of the Lithuanian foreign policy was not generally viewed by the interviewed Lithuanian officials as significantly influenced by strategies of exceptionality or visibility. In other words, when mention was made to Estonia, Latvia, and the new NATO member states, only then the concept of exceptionality received a largely positive response.

These remarks might imply the following conclusions: (1) the Lithuanian political elite are not comfortable with the idea of inscribing Lithuania within a homogenizing ensemble of the Baltic countries or the NATO newcomers, both

\footnotetext{
118 Anonymous interview with a representative form the Lithuanian Delegation to NATO, Bruxelles (June 3, 2010).

${ }^{119}$ Vaitkevičius, supra note 50

120 Vareikis, supra note 52.

121 Evaldas Nekrašas, supra note 62: 138.

122 Anonymous interview, supra note 118 .
} 
categories of states being considered as belonging to the "league $\mathrm{B}^{\prime 123}$; comparing Lithuania to these countries, especially to the two other Baltic states, is possible only from the material perspective (as opposed, for example, to diverging foreign policy goals and their grandeur); (3) the principles at the basis of Lithuanian foreign policy are not perceived as exceptional, since exceptionality, in the eyes of state representatives, would correspond to a diversion from the existing international norms. The recognition and promotion of the latter, as I argue, result in a more profound integration of Lithuania within the Western community.

\subsection{PROFITABILITY OF EXPERTISE IN INTERNATIONAL OPERATIONS}

The process of integration takes different forms and is supposed to relieve small states from the domination of their powerful counterparts. ${ }^{124}$ Such an assumption appeals to shifts in power criteria no longer conforming to the military or economic logic. At this point we can once again, yet more concretely, invoke the concept of normative power, also referred to as "the power of ideas". ${ }^{125}$

Christine Ingebritsen, in her analysis of the Scandinavian countries, arrives at the conclusion that the Nordic states managed to emerge as "a moral superpower". ${ }^{126}$ She argues that Scandinavian representatives play a significant role within international institutions when there is room for suggesting new ideas and reinforcing existing norms. One such norm is in fact the participation in international missions where the civil dimension is the dominant one.

We can refer at this point to another Nordic author Uffe Balslev's standpoint, according to whom Denmark's entrance to NATO cannot be uniquely associated with the provision of security dividends. In the case of Denmark, its NATO membership constitutes only one aspect of its wider engagement in the international arena ${ }^{127}$ (Denmark is for example also actively involved in UN peace operations ${ }^{128}$ ). After the end of the Cold War, the Danish government advised the newly independent states of Central and Eastern Europe, especially the Baltic trio, on proceeding with the implementation of the same foreign policy strategy and provided them with multiple support.

The foreign policy orientation of Lithuania with regard to the PRT of Ghor conforms to the Danish tradition. For example, in the Participation Strategy ${ }^{129}$

\footnotetext{
123 Česlovas Laurinavičius, Raimundas Lopata, and Vladas Sirutavičius, supra note 5: 102.

124 Uffe Balslev, "The Danish Case: International Involvement as the Small State's Remedy for Great Power Dominance": 107; in: Laurent Goetschel, ed., Small States (...), supra note 21.

125 Christine Ingebritsen, Scandinavia in World Politics (Lanham: Rowman and Littlefield Publishers, 2006), p. 2.

126 Ibid.

127 Uffe Balslev, supra note 124: 115.

128 Ibid.: 107.

129 Strategy of the Participation (...), supra note 49.
} 
emphasis is put on the activities implemented by national authorities in the domain of development aid and possibilities of specialization for national experts, which has a positive impact on the state's prestige within the international community. ${ }^{130}$

Also, having been appointed the EU envoy to Afghanistan, considered to be "one of the hotspots in terms of global security", former Lithuanian Minister of Foreign Affairs Vygaudas Ušackas was willing to treat this achievement as a proof that a small state like Lithuania could "be a responsible international player". ${ }^{131}$ Moreover, although recognising NATO and the US as "the main players in terms of security", Ušackas emphasized the "unique capabilities [of the EU] in the area of soft security". ${ }^{132}$ In this sense, the Lithuanian command of the PRT of Ghor obeys the milestones of the European soft interventionist foreign policy.

As a recent memory goes, the American and British governments were not in favour of the deployment of international efforts aimed at reconstructing the Afghan state; on the contrary, the remaining European countries voiced the imperative character of such efforts. ${ }^{133}$ These were finally included in the Bonn Agreement of 2001 and later entrusted to the ISAF in charge of the reconstruction of the territory. ${ }^{134}$

As noted by William Drozdiak with regard to counter-insurgence missions, Europe considers the reconstruction of economic infrastructure and implementation of civil projects as being of greater importance than the projection of military force. ${ }^{135}$ The EU is the largest financial contributor to aid-provision programmes, and European voters express their support to the projection of soft power that manifests "in the form of development aid, educational assistance, and other tools to bolster civil society and democratic institutions in war-torn areas". ${ }^{136}$ Similarly, Cooper considers Brussels as aiming at the promotion of an international society model based on the logic of international socialization. ${ }^{137} \mathrm{~A}$ continuously expanding international cooperation, enhanced by the processes of state-building and reconstruction of post-conflict regions, is supposed to lead to the harmonization of norms, consolidation of multilateral mechanisms and networks, recognition of common values ${ }^{138}$, etc.

Participation in international operations is declared as one of Lithuania's foreign policy priorities since its independence. The command of the PRT of Ghor

\footnotetext{
130 Anonymous interview, supra note 118.

131 Andrew Rettman, "Afghanistan Envoy Flies the Flag for New EU States," Euobserver.com (February

24, 2010) // http://euobserver.com/9/29540 (accessed February 24, 2010).

132 Ibid.

133 Timo Noetzel and Sibylle Scheipers, supra note 20.

134 Ibid.

135 William Drozdiak, supra note 98.

136 Ibid.

137 Robert Cooper, supra note 39, p. 55.

138 Marie De Jerphanion, supra note 16: 132.
} 
seems to provide credibility to such a foreign policy orientation. Yet Vilnius, mostly because of its lack of experience, has much difficulty in achieving tangible results. The normative cause appears to be a necessary but not sufficient condition for democracy promotion.

\subsection{RECONSTRUCTION ACTIVITIES AS A PRACTICAL CHALLENGE FOR}

\section{LITHUANIA}

Lithuania has been participating in international missions since its independence. If we add to this reality the ever more active character of the engagement of Vilnius in this domain, one might deduce Lithuania's specialization within the framework of this specific foreign policy orientation. The command of the PRT of Ghor obliges Lithuania to adapt to practical imperatives relative to the donor community when implementing reconstruction and development cooperation activities.

It might be noticed that among the national vulnerabilities, enumerated in the Participation Strategy ${ }^{139}$, emphasis is put on the recent status of Lithuania as a donor country as well as its lack of "donorship traditions" (Vilnius lacks effective mechanisms of aid provision, experts, and long-standing partners). Moreover, "Lithuania is unable to sufficiently contribute to the civil activities in Afghanistan in terms of domestic economic resources".

These arguments can be illustrated by concrete examples: in 2007, the Lithuanian media wrote about the governor of Ghor general Baz Mohammad Ahmadi's discontent as to the Lithuanian efforts ${ }^{140}$; in 2009 , new governor Sayed Mohammad Iabal Munib voiced the same concerns and argued that support from other states would be inevitable. ${ }^{141}$ Responsible Lithuanian authorities do not seem to neglect this reality: for instance, Juknevičienè noted that Lithuania was unable to provide as much money as Sweden or Germany, whose budget for the reconstruction activities amounted to "hundreds of millions of Euros". ${ }^{142}$

I note as well that, in the context of the economic and financial crisis, reductions in the Lithuanian budget for the implementation of civil projects do not

\footnotetext{
139 Strategy of the Participation (...), supra note 49.

140 Jūratè Skèrytè, "Goro gubernatoriaus netenkina lietuviu pastangos [Lithuania's Efforts Do Not Satisfy the Ghor Governor]," Alfa.It (November 15, 2007) //

http://www.alfa.It/straipsnis/157424/?Goro.gubernatoriaus.netenkina.lietuviu. pastangos=2007-1115_12-19 (accessed June 9, 2010).

${ }^{141}$ BNS, "Goro gubernatorius: provincijos ekonominè situacija - labai sunki [The Ghor Governor: The Economic Situation of the Province Is Very Difficult]," (July 20, 2009) // http://www.delfi.It/news/daily/world/article.php?id=23181732 (accessed February 20, 2010).

142 Andrius Sytas, "Lietuva pripažista nebesugebanti viena vadovauti Afganistano provincijos atstatymui [Lithuania Recognises that It Is No Longer Capable of Commanding Alone the Reconstruction of the Afghan Province]," Alfa.It (July 10, 2009) // http://www.alfa.It/straipsnis/10276632/?Lietuva.pripazista.nebesugebanti.viena.vadovauti.Afganistano.p rovincijos.atstatymui=2009-06-10_12-54 (accessed May 26, 2010).
} 
seem to counter any structural, institutional or ideological obstacle. ${ }^{143}$ The situation characterizing the Lithuanian command of Ghor might be briefly described as follows: financial contributions for the civil dimension of the mission are essentially provided by the partners of Vilnius ${ }^{144}$, such as Japan, the US, Germany, Iceland, Denmark, Croatia, and the EU Commission. ${ }^{145}$

The reconstruction efforts implemented by Lithuanian authorities might be downplayed not only quantitatively but also qualitatively. The cooperation development policy of donor countries is based on the principle according to which cooperation between a given donor and recipient is entitled to reflect partnership relations, instead of patterns of dominance or transmission of specific knowledge or skills uniquely possessed by donor countries. Another important aspect when discussing development cooperation are transnational relations. They refer to the cooperation between donor countries and elements of the society of a recipient country. According to Colonomos, the transnational dimension is the precise instance within which social patterns of conduct are promoted and imitated, and ideas are playing a significant role therein. ${ }^{146}$

Following this logic, I argue that the normative foreign policy of Vilnius, based on democracy promotion, depends on social interactions with members of the Afghan society. Consequently, the reconstruction activities implemented in Ghor should be expected to reflect a transnational aspect. Furthermore, as noted by Lithuanian expert of the Middle East and Arab culture Egdūnas Račius, in order for transnational relations to take place, cultural awareness, i.e. minimal knowledge of the local culture, is crucial, since it facilitates interactions of implicated actors and minimize the need of material and human resources. ${ }^{147}$

As noted by Račius, Lithuania's long-standing engagement in Ghor was obvious already in 2006, which should have encouraged responsible national institutions to adopt a relevant strategy. However, this was done only in 2009. ${ }^{148}$ Such a slow reaction might be attributed to the lack of coordination between the Lithuanian institutions. It might as well as be a consequence of the indifference of responsible national elements with regard to the engagement of Vilnius in Afghanistan. As stated in Lithuania's Participation Strategy, the country does not benefit from all the possible national resources: the Lithuanian government,

143 ELTA, "Lietuva ieško partneriu atkuriant Goro provincija [Lithuania Is Looking for Partners for the Reconstruction of the Ghor Province]," (July 8, 2009) // http://www.balsas.It/naujiena/299487/lietuvaiesko-partneriu-atkuriant-goro-provincija (accessed February 20, 2010).

144 Trakymas, supra note 38.

145 MFA, "Lietuvos veikos Afganistane status quo," supra note 51.

146 Ariel Colonomos, "La sociologie des relations internationales à la recherche d'une morale [Sociology of International Relations in Quest for a Morality]," International Review of Sociology Vol. 12, No. 3 (2002): 509.

147 Egdūnas Račius, "The Cultural Awareness Factor in the Activities of the Lithuanian PRT in Afghanistan," Baltic Security \& Defence Review 9 (2007): 57.

${ }_{148}$ Strategy of the Participation (...), supra note 49. 
parliament and presidency neither pay enough attention to the issue in question nor provide adequate support. ${ }^{149}$ This situation can be explained by the fact that the cause of the Lithuanian engagement in Afghanistan had been conditioned by the MoD, while the MFA was not willing to engage. ${ }^{150}$ The arguments put forward by the MoD were gradually adopted by representatives of other national institutions such as the Seimas. ${ }^{151}$

It would be difficult to explain Lithuania's neglect of the imperatives related to civil activities. For example, it might be considered as a strategy conforming to the logic of instrumentalization, put in motion with the view of gaining security dividends from NATO. It might as well be conceptualized as a process of practical adaptation to the existing international norms. In either case, these two perspectives are not mutually exclusive.

\subsection{THE DEFECTIVE SOCIETAL-CIVIL FOUNDATION OF THE LITHUANIAN ENGAGEMENT}

The efforts of Vilnius to contribute to the development of Afghan civil society also suffer from discredit due to the lack of support from the Lithuanian society regarding the national engagement in Afghanistan. The concept of civil society appeals to "a zone of freedom for individuals to associate with others and for groups to shape their norms, articulate their purposes, and determine for themselves the internal structure of group [...] identity". ${ }^{152}$ As for government, it is supposed to represent the interests of the population forming a civil society, its common interests and identity. ${ }^{153}$ With regard to the Afghan issue and Lithuania, there is a disjuncture between Lithuanian civil society and the national political milieux. The latter's approach might in fact be qualified as elitist and avoiding dialogue.

The Lithuanian government's engagement in the Afghan territory might be contextually associated with the Soviet intervention in the country. This provides specific interest to our analysis in the sense that the Lithuanian conscripts who participated in the Soviet intervention represent collective memory of a "very unconventional" nature. ${ }^{154}$ They also express a negative opinion towards the

\footnotetext{
149 Ibid.

150 Rima Aukštuolytè, Provinciju atkūrimo grupiu veikla Afganistane: rezultatyvumo vertinimas [An Operation of Provincial Reconstruction Teams in Afghanistan: An Assessment of Effectiveness], Bachelor thesis (Vilnius: Vilnius University, 2009).

${ }^{151}$ Interview with Gražvydas Jasutis, representative of the Permanent Delegation of Lithuania to NATO, Bruxelles (June 3, 2010).

152 Nancy L. Rosenblum and Robert C. Post, Civil Society and Government (Princeton, New Jersey: Princeton University Press, 2002), p. 3.

153 Ibid.

154 E-mail interview with Egdūnas Račius (June 7, 2010).
} 
international community activities in Afghanistan in general and the Lithuanian engagement in particular.

The weak political stance of the Afghan veterans as an interest group denotes their vulnerable position, which prevents them from establishing a dialogue with representatives of the government on an equal footing. For instance, at the beginning of 2010, members of the association "Mirage" submitted to the government a bill, in which a strong emphasis was put on a diverging status between the Soviet Afghan veterans and the participants in today's international peace missions; it was consequently required to proceed to the adoption of a law establishing uniform conditions for the two mentioned categories. ${ }^{155}$ However, the answer received from the Lithuanian MoD rejected the possibility of such a legal measure.

The distinction between the participants in engagements abroad in the Soviet times and those of independent Lithuania seems to be only natural for the interviewed members of the Seimas: for example, according to one delegate, these two historical episodes "differ in essence, and the Lithuanian society is aware of that". ${ }^{156}$ On the contrary, according to the Afghan veteran sergeant Zigmas Stankus ${ }^{157}$, today's efforts of the international community to reconstruct Afghanistan is a mere occupation. He draws attention to the fact that public arguments formulated by representatives of the Lithuanian government and those found in the media make no mention of the activities of special forces; Stankus compares these military activities to those implemented by the Soviet army. It is also to be noticed that, as affirmed by Stankus, the Afghan nation has never been homogeneous, which denotes the ignorance of Western countries as to the Afghan realities.

Such a position referring to the importance of understanding regional specificities converges with Račius' analysis: both Račius and Stankus recognise the fact that the lack of knowledge of regional cultural realities impinges on the efficiency of civil projects implemented by the Lithuanian authorities in Ghor. As well, they agree that the decision taken by Vilnius to command the PRT of Ghor was "one of the most stupid, irresponsible, and even possibly criminal decisions [ever taken by the Lithuanian government]". ${ }^{158}$

\footnotetext{
${ }^{155}$ With Regard to the Participants in the Afghan War, Resolution of the Association of the Participants in the Afghan War (March 25, 2010), communicated via e-mail by Zigmas Stankus (May 18, 2010).

156 Pečeliūnas, supra note 52 .

157 E-mail interview with Zigmas Stankus (May 18, 2010).

158 Deividas Šlekys, "E. Račius: apie Afganistana, pinigus, karius ir nutylejimus [E. Račius: About Afghanistan, Money, Soldiers and Reticence]," Bernardinai.lt (October 10, 2010) // http://www.bernardinai.lt/straipsnis/2006-10-10-e-racius-apie-afganistana-pinigus-karius-irnutylejimus/28097 (accessed May 28, 2010).
} 
However, Stankus criticises the military activities of the international community, while Račius draws attention to the ignorance of Lithuanian authorities with regard to cultural aspects of the region. The lack of coherence in the argumentation criticising the Lithuanian engagement in Afghanistan ${ }^{159}$ might be due to a non-going public dialogue concerning the Afghan issue which ultimately appears to be an ideological one. ${ }^{160}$ Consequently, arguments reflecting an ideological register result in counter-arguments of the same kind. Such official rhetoric put forward publicly by Lithuanian representatives amount to "a bluff" and "skulduggery", since, according to Račius, the Lithuanian society does not receive credible information about the engagement of Vilnius in Afghanistan and is even being "misinformed in the form of messages of public relations, transmitted by the national institutions".

A propaganda-related aspect validates the thesis of elitism characterizing the Lithuanian political strata, which results in its ever increasing disjuncture from the civil society. This gap brings discredit to the democratic legitimacy of the Lithuanian government and its policy strategies, as well as to an eroding national and social cohesion, deprived of which "no state is strong". 161 "An efficient state organisation influencing social cohesion" is the main criterion which confers significance to or reduces the importance of other criteria to be mobilized in the analysis of a state's weight and influence on the international arena. ${ }^{162}$

\section{CONCLUSIONS}

The analysis presented above argues for the existence of possibilities for small states to act on an international scale and to implement their (relatively) own foreign policy corresponding to their national interests. The integrationist dynamics of the international arena contradicts the zero-sum thesis, according to which big states are able to pursue their national interests thanks to a favourable structural distribution of power resources, while small states are rendered inactive. In the actual case of Afghanistan, there is an obvious lack of data which could prove existing contradictions between interests and strategies of big (or powerful) states and those of their smaller counterparts.

\footnotetext{
159 For example, when asked to consider if the Estonian or Latvian engagement in Afghanistan would seem more appropriate, Račius recognised that he did not possess enough knowledge relative to the participation of the Lithuanian neighbours in the ISAF. We might then criticise the expert's analysis as lacking comparative perspective and hence limited.

${ }_{160}$ As noted by Stankus, his question to the then Minister of Defense Juozas Olekas as to the manner in which today's occupation of Afghanistan differed from the one under the Soviet regime, received an answer putting forward the argument of diverging ideologies.

161 Pascal Boniface, ed., La puissance internationale [International Power] (Paris: Dunod, 1994), p. 25; Barry Buzan, supra note 74, p. 97-98.

162 Barry Buzan, supra note 74 , p. 97-98
} 
The fact that the allies do not manifest the same level of engagement in Afghanistan is attributed in this article to their divergent national interests ${ }^{163}$ or, more precisely, to the benefits a specific country is able to reap thanks to its engagement in Afghanistan. Lithuania's active commitment to the coalition forces is explained by the possibility of its deeper integration within the West.

The engagement of Vilnius in Afghanistan might be considered as a strategy which provides the Lithuanian government with the possibility to gain reputation defined as "a judgement of someone's character (or disposition) that is then used to predict or explain future behaviour". ${ }^{164}$ In other words, reputation is based on the coherence of a state's actions. It refers to the interdependence between the same state's past actions and those to be expected in the future. As for Lithuania, it might be argued that, having only recently regained its independence and become a subject at the international level, it still lacks credibility.

Declared as being at the top of the national foreign policy priorities, Lithuania's engagement in Afghanistan provides Vilnius with a practical window of opportunity to become a full-fledged member of the Transatlantic community. However, this politics of becoming should not be seen as a strategy conforming to a somewhat universal essence or a deterministic and inevitable condition. ${ }^{165}$

The first part of the article analysed the Lithuanian government's engagement in the ISAF as providing Lithuania with a strengthened national security vis-à-vis Russia. The attempts of Vilnius to follow its security logic does not contradict international efforts to counter terrorism. Aspiring to a more intimate integration within the West, representatives of the Lithuanian government embrace specific elements from the Western political discourse and tend to argument the country's engagement in Afghanistan as indispensible to defending national interests. Secondly, I tried to enrich the conception of Lithuania's pursuit of security dividends by introducing in my analysis a normative aspect. This methodological flexion lessens the weight of a deterministic perspective akin to (neo)realism in general and to traditional security studies in particular. It also recognises that Lithuania's political elite possess an interactive capacity to orient state behaviour in the sphere of foreign policy. Public arguments based on normative obligations and responsibility stem from a newly acquired conscience of belonging to the Western community and thus cannot be conceived as merely rhetoric justifications for Lithuania's pre-established and analytically-distinct national security interests. ${ }^{166}$

\footnotetext{
163 Mancur Olson Jr. and Richard Zeckhauser, supra note 14: 266.

164 Jonathan Mercer, Reputation and International Politics (Ithaca: Cornell University Press, 1996$),$ p. 6.

165 Maria Mälksoo, supra note 7, p. 37.

166 Ibid., p. 138.
} 
Aspiring to a more profound integration within the West and to recognition among its Western counterparts, "the Lithuanian political corpus"167 lacks neither determination nor activism in order to achieve this goal, elevated to the top of its national interests. Yet Vilnius possesses limited financial as well as human resources. Consequently, it cannot adequately respond to the challenge of heterogeneous practices the integration process implies.

The Lithuanian engagement in Afghanistan continues to be dominated by the military aspect, not the civil one. As the large majority of representatives of the Lithuanian government perceive it, national security might be reinforced only if military inputs are made to the ISAF efforts. Such a position does not correspond to the social realities of international arena: the adoption of intersubjective perceptions by the Lithuanian political elite is supposed to confer on its relations with the allies more quality if not intimacy. Moreover, having engaged its responsibility upon the decision to take up the command of the PRT of Ghor (an operational entity which, by its mere name, appeals to activities of non-military nature), the Lithuanian government needs to strive for enhanced efficiency in implementing civil programmes. This practical insight reflects the conception of the international arena as a space of social interactions, which provides the possibility to construct an image of oneself. The Afghan terrain serves as a possible leverage of influence for the Lithuanian government to inscribe its engagement within the framework of a coherent pursuit of the country's integration into the Western community, be it in the security, normative or practical domain.

Lastly, it is important to note that the most serious challenge the Lithuanian government seems to be facing is - paradoxically - an internal (versus international) one. The political strata in Lithuania appear to be lacking democratic legitimacy in the sense that there is a disjuncture between the political elite ${ }^{168}$ and an emerging civil society. Such a defective national cohesion, wherever it is manifest, might condemn any state to being weak. Once the Lithuanian government succeeds in solving this problem, it will gain more credibility on an international scale in order to advance with confidence the principles of its own foreign policy.

\footnotetext{
167 Račius, supra note 154.

168 According, for instance, to Jasutis, debates on the Afghan issue should not take place within the civil society, since its members are simply devoid of much information qualified as "confidential" (Jasutis, supra note 151).
} 


\section{BIBLIOGRAPHY}

1. Afghanistan International Security Assistance Force. "ISAF: Key Facts and Figures." (March 4, 2011) //

http://www.isaf.nato.int/images/stories/File/Placemats/PLACEMAT.MARCH\%2 004.pdf (accessed March 6, 2011).

2. Afghanistan ISAF. "ISAF Placement Archives." (March 2011) //

http://www.isaf.nato.int/isaf-placemat-archives.html (accessed March 10, 2011).

3. Associated Press (AP). "Nato Air Forces to Train over Baltic Countries." (March http://seattletimes.nwsource.com/html/nationworld/2011229377_apeunatoba Iticairpatrols.html?syndication=rss (accessed March 2, 2010).

4. Army of the Republic of Lithuania. "Tarptautiniu operaciju finansavimas [The Financing of International Operations]." (2010) //

http://kariuomene.kam.It/It/tarptautines_operacijos_786/tarptautiniu_misiju_ finansavimas.html (accessed May 23, 2010).

4. Army of the Republic of Lithuania. "Ypatingosios paskirties tarnyba (YPT) [Special Purpose Service]" //

http://kariuomene.kam.It/It/kariuomenes_struktura/specialiuju_operaciju_paj egos/ypatingosios_paskirties_tarnyba_ypt.html (accessed April 25, 2010).

5. Aukštuolytè, Rima. Provinciju atkūrimo grupiu veikla Afganistane: rezultatyvumo vertinimas [An Operation of Provincial Reconstruction Teams in Afghanistan: An Assessment of Effectiveness]. Bachelor thesis. Vilnius: Vilnius University, 2009.

6. Bačiulis, Audrius. "Rusija netikètai atsigręžè i Lietuvą [Russia Has Unexpectedly Turned to Lithuania]." Veidas (February 15, 2010): 18-19.

7. Balslev, Uffe. "The Danish Case: International Involvement as the Small State's Remedy for Great Power Dominance": 107-124. In: Laurent Goetschel, ed. Small States Inside and Outside the European Union: Interests and Policies. Dordrecht: Kluwer Academic Publishers, 1998.

8. Bennet, Andrew, Joseph Lepgold, and Danny Unger. Friends in Need: Burden Sharing in the Gulf War. Bloomsburg: Macmillan Press Ltd, 1997.

9. BNS. "Audronius Ažubalis: dèl indèlio Afganistane Lietuva gali tarti griežtesni žodi NATO [Audronius Ažubalis: Thanks to its Contributions to Afghanistan, Lithuania Is Able to Speak More Loudly within NATO]." (April 2, 2010) // http://www.balsas.It/naujiena/246236/audronius-azubalis-del-indelioafganistane-lietuva-gali-tarti-grieztesni-zodi-nato (accessed April 27, 2010). 
10. BNS. "D. Žalimas: apie konkrečius gynybos planus nekalbama sąmoningai [D. Žalimas: Nobody Speaks about Specific Defense Plans Consciously]." (April $15,2010) / /$ http://www.delfi.It/news/daily/lithuania/dzalimas-apie-konkrecius-gynybosplanus-nekalbama-samoningai.d?id=31077633 (accessed April 15, 2010).

11. BNS. "Goro gubernatorius: provincijos ekonominè situacija - labai sunki [The Ghor Governor: The Economic Situation of the Province Is Very Difficult]." (July 20, 2009) //

http://www.delfi.It/news/daily/world/article.php?id=23181732 (accessed February 20, 2010).

12. BNS. "Kariuomenès vadas V. Tutkus: NATO oro policija - vienintelè išeitis Lietuvai [The Chief of Army V. Tutkus: The NATO Air Police Is the Only Resort for Lithuania]." (July 20, 2006) //

http://www.Irytas.It/-11541658091153759738-kariuomen\%C4\%97s-vadas-vtutkus-nato-oro-policija-vienintel\%C4\%97-i\%C5\%A1eitis-lietuvai.htm (accessed May 30, 2010).

13. BNS. "P. Vaitiekūnas: Lietuvos veikla Afganistane - vienas didžiausiu tarptautiniu isipareigojimy [P. Vaitiekūnas: The Lithuanian Activities in Afghanistan Constitute One of the Most Significant International Engagements [of Lithuania]." (November 26, 2007) //

http://www.vtv.It/naujienos/uzsienio-politika/p.-vaitiekunas-lietuvos-veiklaafganistane-vienas-didziausiu-tarptautiniu-isipareig-3.html (accessed June 5, 2010).

14. BNS. "R.Juknevičienè: pildyti NATO biudžetą mažiau skausminga nei prarasti oro policija [R. Juknevičienè: It Is Less Painful to Contribute to the NATO Budget than to Lose the Air Police]." (February 10, 2010) // http://www.alfa.It/straipsnis/10314711/?Jukneviciene..pildyti.NATO.biudzeta. maziau.skausminga..nei. prarasti.oro.policija=2010-02-10_17-50 (accessed May 30, 2010).

15. BNS. "Saugumo srityje Lietuvą ir JAV sieja puiki dvišalè ir NATO partnerystè [Lithuania and the US Has a Superb Bilateral Partnership in the Security Domain]." (March 25, 2010) // http://www.nato.It/jav-ambasadore-saugumo-srityje-lietuva-ir-jav-siejapuiki-dvisale-ir-nato-partneryste/ (accessed May 30, 2010).

16. Boniface, Pascal, ed., La puissance internationale [International Power]. Paris: Dunod, 1994.

17. Buzan, Barry. People, States and Fear: An Agenda for International Security Studies in the Post-Cold War Era. Hertfordshire: Harvester Wheatsheaf, 1991. 
18. Buzan, Barry, Ole Waever, and Jaap De Wilde. Security: A New Framework for Analysis. London: Lynne Rienner Publishers, 1998.

19. Buzan, Barry. "Will the Global War on Terrorism Be the New Cold War?" International Affairs Vol. 82, No. 6 (2006): 1101-1118.

20. Colonomos, Ariel. "La sociologie des relations internationales à la recherche d'une morale [Sociology of International Relations in Quest for a Morality]." International Review of Sociology Vol. 12, No. 3 (2002): 507-520.

21. Colonomos, Ariel. La morale dans les relations internationales [Morality in International Relations]. Paris: Odile Jacob, 2005.

22. Cooper, Robert. La fracture des nations. Ordre et chaos au XXI siècle [The Breaking of Nations. Order and Chaos in the Twenty-First Century]. Paris: Denoël (Médiations), 2004.

23. Crowards, Tom. "Defining the Category of Small States." Journal of International Development 14 (2002): 143-179.

24. De Jerphanion, Marie. "Vers un rapprochement de la morale et de la Realpolitik ? [Towards a Rapprochement between the Morality and Realpolitik?]" Revue internationale et stratégique Vol. 67, No. 3 (2007): 127134.

25. Dèl Afganistano karo dalyviu [With Regard to the Participants in the Afghan War]. Resolution of the Association of the Participants in the Afghan War (March 25, 2010).

26. Dèl Lietuvos Respublikos vyriausybès 2008-2012 mety programos igyvendinimo priemoniu patvirtinimo [On the adoption of the implementation means of the Programme of the Government of the Republic of Lithuania for 2008-2012]. Decision No. 189 adopted by the Government of the Republic of Lithuania. (February 25, 2009) //

http://www3.Irs.It/pls/inter3/dokpaieska.showdoc_l?p_id=354702\&p_query= \&p_tr2= (accessed May 24, 2010).

27. Dirgytė, Eglè. "A. F. Rasmussenas: nebūtu teisinio pagrindo pašalinti Lietuvą iš NATO [A.F.Rasmussen: There Would Be No Legal Foundation to Exclude Lithuania from NATO]." Delfi.lt (April 22, 2010) // http://www.delfi.lt/news/daily/lithuania/afrasmussenas-nebutu-teisiniopagrindo-pasalinti-lietuva-is-nato.d?id=31381883 (accessed April 27, 2010).

28. Dobry, Michel. "Introduction: When Transitology Meets Simultaneous Transitions": 1-16. In: Michel Dobry, ed. Democratic and Capitalist Transitions in Eastern Europe. Lessons for the Social Sciences. Dordrecht: Kluwer Academic Publishers, 2000. 
29. Drozdiak, William. "The Brussels Wall." Foreign Affairs Vol. 89, No. 3 (MayJune 2010): 7-12.

30. ELTA. "Aukštas NATO pareigūnas: Lietuva - patikima NATO partnerè [A Highlevel NATO Official: Lithuania Is NATO's Trustworthy Ally]." (April 30, 2009) // http://www.balsas.It/naujiena/250374/aukstas-nato-pareigunas-lietuvapatikima-nato-partnere (accessed May 30, 2010).

31. ELTA. "Lietuva ieško partneriu atkuriant Goro provincija [Lithuania Is Looking for Partners for the Reconstruction of the Ghor Province]." (July 8, 2009) // http://www.balsas.It/naujiena/299487/lietuva-iesko-partneriu-atkuriant-goroprovincija (accessed February 20, 2010).

32. Embassy of the United States. "U.S.-Lithuania Relations: Next Steps." (March 25, 2010) // http://vilnius.usembassy.gov/tspmi.html (accessed March 25, 2010).

33. Fawn, Rick. "Alliance Behaviour, the Absentee Liberator and the Influence of Soft Power: Post-Communist State Position over the Iraq War in 2003." Cambridge Review of International Affairs Vol. 19, No. 3 (2006): 465-480.

34. Foreign Policy Affairs and European Policy (November 17, 2008) // http://www3.Irs.It/docs2/KCQRLFQZ.PDF (accessed March 23, 2010).

35. Gärtner, Heinz. "Small States and Alliances": 1-10. In: Heinz Gärtner and Erich Reiter, eds. Small States and Alliances. Heidelberg: Physica-Verlag, 2001.

36. Goetschel, Laurent. "Introduction": 9-12. In: Laurent Goetschel, ed. Small States Inside and Outside the European Union: Interests and Policies. Dordrecht: Kluwer Academic Publishers, 1998.

37. Goetschel, Laurent. "The Foreign and Security Policy Interests of Small States in Today's Europe": 13-32. In: Laurent Goetschel, ed. Small States Inside and Outside the European Union: Interests and Policies. Dordrecht: Kluwer Academic Publishers, 1998.

38. Hey, Jeanne A. K. "Introducing Small State Foreign Policy": 1-12. In: Jeanne A. K. Hey, ed. Small States in World Politics: Explaining Foreign Policy Behavior. Boulder: Lynner Rienner Publisher, 2003.

39. Ingebritsen, Christine. Scandinavia in World Politics. Lanham: Rowman and Littlefield Publishers, 2006. 
40. Ingebritsen, Christine. "Norm Entrepreneurs: Scandinavia's Role in World Politics": 273-285. In: Christine Ingebritsen, ed. Small States in International Relations. Seattle: University of Washington Press, 2006.

41. Jackevičius, Mindaugas. "R.Juknevičienè: i Afganistana nesiunčiame nè pusès kariu, kiek leidžia Seimas [R.Juknevičienè: We Do Not Send to Afghanistan Even Half of the Soldiers Allowed by the Seimas]." Delfi.lt (April 6, 2011) // http://www.delfi.lt/news/daily/lithuania/rjukneviciene-i-afganistananesiunciame-ne-puses-kariu-kiek-leidzia-seimas. $d$ ? $i d=44067047$ (accessed April 12, 2011).

42. Keohane, Robert O. "Lilliputians' Dilemmas: Small States in International Politics." International Organization Vol. 23, No. 2 (1969): 291-310.

43. Keohane, Robert O. "The Big Influence of Small Allies." Foreign Policy No. 2 (Spring 1971): 161-182.

44. Korski, Daniel. "Afghanistan: Europe's Forgotten War." European Council on Foreign Relations. (2008) // http://ecfr.3cdn.net/fcdc73b8da7af85936_q8m6b5o4j.pdf (accessed March 5, 2010).

45. Krause, Volker, and David Singer. "Minor Powers, Alliances, and Armed Conflict: Some Preliminary Patterns": 15-25. In: Heinz Gärtner and Erich Reiter, eds. Small States and Alliances. Heidelberg: Physica-Verlag, 2001.

46. Laroche, Josepha. Politique internationale [International Politics]. $2^{\text {nd }}$ ed. Paris: L.G.D.J., 2000.

47. Lasserre, Isabelle. "Le Mistral, objet flottant de convoitises [The Mistral: A Floating Objet of Covetousness]." Lefigaro.fr (April 8, 2010) // http://www.lefigaro.fr/international/2010/04/09/0100320100409ARTFIG00003-lemistral-objet-flottant-de-convoitises-.php (accessed May 27, 2010).

48. Laurinavičius, Česlovas, Raimundas Lopata, and Vladas Sirutavičius. "Kritinis požiūis i Lietuvos užsienio politiką: kas pasikeitè nuo Augusto Voldemaro laiku? [A Critical Approach towards the Lithuanian Foreign Policy: What Has Changed since the Times of Augustas Voldemaras?]" Politologija Vol. 54, No. 2 (2009): 91-122.

49. Laurinavičius, Marius. "Akibrokštai partneriams taps Lietuvos užsienio politikos kasdienybe? [Will Lapsus Become Part of the Lithuanian Foreign Policy Daily Life?]" Lrytas.It (April 9, 2010) // http://www.Irytas.It/-12707989501269486198-m-laurinavi\%C4\%8Diausblogas-akibrok\%C5\%A1 tai-partneriams-taps-lietuvos-u\%C5\%BEsieniopolitikos-kasdienybe.htm (accessed May 26, 2010). 
50. Lebow, Richard Ned. "Fear, Interest and Honour: Outlines of a Theory of International Relations." International Affairs Vol. 82, No. 3 (2006): 431-448.

51. Lietuvos Respublikos dalyvavimo tarptautinès bendruomenès veikloje Afganistano Islamo Respublikoje 2009-2013 metu strategija [Strategy of the Participation of the Republic of Lithuania in the International Community Activities in the Islam Republic of Afghanistan 2009-2013]. Adopted by the decision No 989 of the Government of the Republic of Lithuania. (August 19, 2009) //

http://www3.Irs.It/pls/inter3/dokpaieska.showdoc_l?p_id=351998\&p_query= \&p_tr2= (accessed January 15, 2010).

52. Linkevičius, Linas. "Life After Enlargement." Baltic Defence Review Vol. 1, No. 9 (2003): 102-107.

53. Lopata, Raimundas. "Europos Sajunga ir Rusija: ką reiškia "ir"? [European Union and Russia: What does "and" mean?]" Lrytas.It (May 14, 2010) // http://www.Irytas.It/-12738269801271897730-europos-s\%C4\%85junga-irrusija-k\%C4\%85-rei\%C5\%A1kia-ir.htm (accessed May 24, 2010).

54. Mälksoo, Maria. The Politics of Becoming European: A Study of Polish and Baltic Post-Cold War Security Imaginaries. London: Routledge, 2010.

55. Manent, Pierre. Cours familier de philosophie politique [Informal Course of Political Philosophy]. Paris: Gallimard, 2001.

56. Männik, Erik. "Small States: Invited to NATO - Able to Contribute?" Defense \& Security Analysis Vol. 20, No. 1 (2004): 21-37.

57. Mercer, Jonathan. Reputation and International Politics. Ithaca: Cornell University Press, 1996.

58. Ministry of Defense. "2008 m. krašto apsaugos sistemos biudžetas [The Budget of the Ministry of Defense in 2008]." Krašto apsauga Vol. 14, No. 143 (2008): $1 / /$

http://www.kam.It/It/naujienos_874/karine_ziniasklaida_655/krasto_apsauga _718/2008_m._krasto_apsaugos_numeriai/krasto_apsauga_2008_m._rugpjut is.html, (accessed May 23, 2010).

59. Ministry of Defense. Lietuvos nacionalinio saugumo strategija pateiks saugios ateities vizija [The Lithuanian National Security Strategy Is to Provide a Vision of a Secure Future]. (February 18, 2002) //

http://www.kam.It/It/naujienos_874/archyvas_930/ziniu_archyvas_2002_met ai/ziniu_archyvas_2002-

02/lietuvos_nacionalinio_saugumo_strategija_pateiks_saugios_ateities_vizija. html?backlink=\%252Flt\%252Fpaieska\%252Fresults\%252Fp10.html (accessed May 29, 2010). 
60. Ministry of Foreign Affairs. "Kova su terorizmu [War Against Terrorism]" // http://www.urm.It/index.php?-1810366038 (accessed May 29, 2010).

61. NATO. "Address to the Nation by Valdas Adamkus, President of the Republic of Lithuania, in Response to Terrorist Attack in the US." (September 14, 2001) // http://www.nato.int/pfp/lt/speeches/2001-09-14.html (accessed June 5, 2010).

62. NATO. "Financial and Economic Data Relating to NATO Defense. Defense Expenditure of NATO Countries." (February 19, 2009) // http://www.nato.int/docu/pr/2009/p09-009.pdf (accessed May 23, 2010).

63. NATO. "Prague Summit Declaration." (November 21, 2002) // http://www.nato.int/docu/pr/2002/p02-127f.htm (accessed May 29, 2010).

64. NATO. "Specialiuju operaciju pajègu eskadronas Aitvaras vèl visu pajègumu dalyvaus tarptautineje operacijoje Afganistane [The Squadron of Special Operation Forces Aitvaras Will Participate Again with All Its Capacities in the International Operation in Afghanistan]." (April 13, 2010) // http://www.nato.It/specialiuju-operaciju-pajegu-eskadronas\%e2\%80\%9eaitvaras\%e2\%80\%9c-vel-visu-pajegumu-dalyvaustarptautineje-operacijoje-afganistane/ (accessed May 30, 2010).

65. NATO. "Statement by the Seimas of the Republic of Lithuania on the Acts of Terrorism against the USA." (September 12, 2001) // http://www.nato.int/pfp/lt/speeches/2001-09-12.html (accessed June 5, 2010).

66. Nay, Olivier, ed. Lexique de science politique [Glossary of Political Science]. Paris: Editions Dalloz, 2008.

67. Nekrašas, Evaldas. "Kritiniai pamąstymai apie Lietuvos užsienio politiką [Critical Reflections on the Lithuanian Foreign Policy]." Politologija Vol. 54, No. 2 (2009): 123-142 // http://www.leidykla.vu.It/fileadmin/Politologija/54/123142.pdf (accessed March 15, 2010).

68. Neumann, Iver B., and Sieglinde Gstöhl. "Introduction. Lilliputians in Gulliver's World?": 3-38. In: Christine Ingebritsen, ed. Small States in International Relations. Seattle: University of Washington Press, 2006.

69. Noetzel, Timo, and Sibylle Scheipers. "Coalition Warfare in Afghanistan: Burden-Sharing or Disunity?" Chatham House Briefing Paper (2007) // http://www.chathamhouse.org.uk/files/9878_bp1007afghanistan.pdf (accessed February 18, 2010).

70. Norkus, Renatas. "Lithuania's Contribution to International Operations: Challenges for a Small Ally." Baltic Security \& Defense Review 8 (2006): 167$171 / /$ 
http://www.bdcol.ee/fileadmin/docs/bsdr/8-

Small\%20Allies\%20in\%20International\%200perations-

Renatas\%20Norkus.pdf (accessed March 18, 2010).

71. Olson, Mancur Jr., and Richard Zeckhauser. "An Economic Theory of Alliances." The Review of Economic and Statistics Vol. 48, No. 3 (1966): 266279.

72. Percival, Debra. "La politique lituanienne de développement se tourne vers I'Est [Lithuania's Development Policy Is Turning Eastwards]." Le Courrier 9 (2009) //

http://www.acp-eucourier.info/A-politica-de-desenvolvim.903.0.html?\&L=2 (accessed March 9, 2010).

73. Račius, Egdūnas. "The Cultural Awareness Factor in the Activities of the Lithuanian PRT in Afghanistan." Baltic Security \& Defense Review 9 (2007): 57-78.

74. Radžvilas, Vytautas. "Tiesos valanda: neivykusi valstybė II (Pamąstymai Europos dienos proga) [The Moment of Truth: A Non-Occurred State II (Reflections on the Occasion of the Europe Day)]." Lrytas.It (April 29, 2010) // http://www.Irytas.It/-12725411511270481841-tiesos-valandane\%C4\%AFvykusi-valstyb\%C4\%97-ii-pam\%C4\%85stymai-europos-dienosproga.htm (accessed May 24, 2010).

75. Radžvilas, Vytautas. "Tiesos valanda: nejvykusi valstybè I (Pamąstymai Europos dienos proga, skiriama šviesiam L. Kaczynskio atminimui) [The Moment of Truth: A Non-Occurred State I (Reflections on the Occasion of the Europe Day, Dedicated to the Memory of L. Kaczynski)]." Lrytas.It (April 22, 2010) //

http://www.Irytas.It/-12719341291269894654-tiesos-valandane\%C4\%AFvykusi-valstyb\%C4\%97-i-pam\%C4\%85stymai-europos-dienosproga-skiriama-\%C5\%A1viesiam-I-kaczynskio-atminimui.htm (accessed May 24, 2010).

76. Reiter, Erich. "Introductory Comments on the Objective of the Small States and Alliances Workshop": 11-14. In: Heinz Gärtner and Erich Reiter, eds. Small States and Alliances. Heidelberg: Physica-Verlag, 2001.

77. Rettman, Andrew. "Afghanistan Envoy Flies the Flag for New EU States." Euobserver.com (February 24, 2010) // http://euobserver.com/9/29540 (accessed February 24, 2010).

78. Rosenblum, Nancy L., and Robert C. Post. Civil Society and Government. Princeton: Princeton University Press, 2002. 
79. Rothstein, Robert L. Alliances and Small Powers. New York: Columbia University Press, 1968.

80. Sandler, Todd. Global Collective Action. New York: Cambridge University Press, 2004.

81. Skèrytè, Jūratè. "Goro gubernatoriaus netenkina lietuviu pastangos [Lithuania's Efforts Do Not Satisfy the Ghor Governor]." Alfa.lt (November 15, 2007) //

http://www.alfa.It/straipsnis/157424/?Goro.gubernatoriaus.netenkina.lietuviu. pastangos=2007-11-15_12-19 (accessed June 9, 2010).

82. Socor, Vladimir. "Lithuania to Lead NATO Unit in Afghanistan." Eurasia Daily Monitor Vol. 33, No. 2 (2005) //

http://www.jamestown.org/single/?no_cache=1\&tx_ttnews\%5Btt_news\%5D

$=27547$ (accessed May 22, 2010).

83. Swannell, Matthew (Major), Bill Moeller, and HQ ISAF PRT Office. ISAF PRT Handbook, 3rd ed. (February 3, 2007).

84. Sytas, Andrius. "Lietuva pripažista nebesugebanti viena vadovauti Afganistano provincijos atstatymui [Lithuania Recognises that It Is Being No Longer Capable of Commanding Alone the Reconstruction of the Afghan Province]." Alfa.It (July 10, 2009) //

http://www.alfa.It/straipsnis/10276632/?Lietuva.pripazista.nebesugebanti.vie na.vadovauti.Afganistano.provincijos.atstatymui=2009-06-10_12-54 (accessed May 26, 2010).

85. Sytas, Andrius. "Kubilius: šiais ir kitais metais iš Goro nesitrauksime [Kubilius: We Will Not Retreat from Ghor this Year]." Alfa.lt (August 19, 2009) // http://www.alfa.It/straipsnis/10286774/?Kubilius..siais.ir.kitais.metais.is.Goro .provincijos.nesitrauksime=2009-08-19_16-44 (accessed May 27, 2010).

86. Šlekys, Deividas. "E. Račius: apie Afganistana, pinigus, karius ir nutylejjimus [E. Račius: About Afghanistan, Money, Soldiers and Reticence]." Bernardinai.lt (October 10, 2010) //

http://www.bernardinai.It/straipsnis/2006-10-10-e-racius-apie-afganistanapinigus-karius-ir-nutylejimus/28097 (accessed May 28, 2010).

87. United Nations Security Council. Resolution 1368 (September 12, 2001) // http://daccess-ddsny.un.org/doc/UNDOC/GEN/N01/533/82/PDF/N0153382.pdf?OpenElement (accessed February 18, 2010).

88. World Bank. "GDP Ranking" // http://siteresources.worldbank.org/DATASTATISTICS/Resources/GDP.pdf (accessed May 17, 2010). 
89. World Bank. "Population, Total" //

http://data.worldbank.org/indicator/SP.POP.TOTL (accessed May 17, 2010).

90. World Bank. "World Development Indicators 2010" //

http://data.worldbank.org/sites/default/files/wdi-final.pdf (accessed April 22, 2011). 